\title{
Badania nad historią kobiet w Polsce w XVI-XVIII wieku w latach 2011-2020. Niezmienna atrakcyjność, ale czy nowe pytania?
}

\section{Summary}

\section{Studies on the history of women in Poland of the $16^{\text {th }}-18^{\text {th }}$ century in the years 2011-2020: Unchanging attractiveness yet new questions?}

Research into the place of women in history, feminism and gender is conducted in many countries of the world, now has a wide reach and is already characterized by an avalanche of literature. The article discusses the achievements of research on the history of women on Polish lands in the early modern period, in the second decade of the $21^{\text {st }}$ century. It reviews several groups of source publications devoted to women in the $16^{\text {th }}-18^{\text {th }}$ century (memoirs, diaries and travel journals, correspondence, wills), which always affect the intensity of historical research. The review of monographic achievements of women's historiography of the last decade is presented in three conventional, extensive theme blocks: women in the family and beyond it (body, sexuality, love and emotions as well as intra-family relations); their education and knowledge, work in towns and in the country, as well as conflicts with law; and the third: women's participation in politics, culture and religion. The work suggests the further development of women studies in terms of the number of studies and the research problems. It also draws attention to the need for new research methods in the historian's workshop, such as social network analysis (SNA), proposed by sociologists, and successfully applied already in Western historical science. The author signalizes certain gaps in research in the history of women in the old-Polish period, which are also quite numerous for the next two centuries, and suggests an urgent need for writing a research-based synthesis of the history of women in Polish lands.

Keywords: women's history, research review, primary source publications, studies, Poland of the $16^{\text {th }}-18^{\text {th }}$ century

\section{Streszczenie}

Badania nad miejscem kobiet w historii, feminizmem i gender prowadzone są w wielu krajach świata, mają obecnie szeroki zasięg i charakteryzują się już wręcz lawinowym przyrostem literatury. Na tym tle artykuł charakteryzuje dorobek badań dotyczących historii kobiet na ziemiach polskich we wczesnej dobie nowożytnej, powstały w drugim dziesięcioleciu XXI w. Autor dokonuje w nim przeglądu 
różnych grup wydawnictw źródłowych zarówno poświęconych kobietom, jak i przez nie wytworzonych w XVI-XVIII w. (pamiętniki, diariusze i dzienniki podróży, korespondencja, testamenty), które zawsze wpływają na intensywność badań historycznych. Z kolei przegląd monograficznych osiągnięć historiografii kobiecej ostatniego dziesięciolecia został zaprezentowany w trzech umownych, rozbudowanych, blokach tematycznych: kobiety w rodzinie i poza nią (ciało, seksualność, miłość i emocje oraz relacje wewnątrzrodzinne); ich edukacja i wiedza, praca w miastach i na wsi oraz konflikty z prawem, i jako trzeci - udział kobiet w polityce, kulturze i religii. Praca wskazuje na dalszy rozwój studiów kobiecych w sensie przyrostu liczby prac i poruszanej problematyki. Zwraca także uwagę na potrzebę stosowania nowych metod badawczych w warsztacie historyka, jak np. metody analizy sieci społecznych (Social Network Analysis - SNA), zaproponowanej przez socjologów, i z powodzeniem stosowanej już w zachodniej nauce historycznej. Autor sygnalizując niektóre luki badawcze w historii kobiet w dobie staropolskiej, których nie brakuje także dla dwóch następnych stuleci, wskazuje na pilną potrzebę napisania naukowej syntezy dziejów kobiet na ziemiach polskich.

Słowa kluczowe: historia kobiet, przegląd badań, wydawnictwa źródłowe, opracowania, Polska XVI-XVIII wieku

\section{Uwagi wstępne}

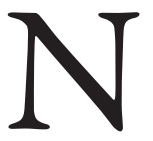

arodziny historii kobiet jako nowego nurtu badawczego w historiografii powszechnej i myśli historycznej przypadają na schyłek lat sześćdziesiątych i początek siedemdziesiątych minionego stulecia ${ }^{1}$. U jego podstaw, oprócz aktywności ruchu emancypacyjnego kobiet w USA, w Anglii i we Francji, legły również przemiany dokonujące się w dotychczasowej praktyce histograficznej, które - po odrzuceniu historii wydarzeniowej na rzecz historii społecznej - zmierzały do włączenia w jej zakres także historii życia i kultury ${ }^{2}$. Historia codzienności i mikrohistoria, oprócz nowoczesnej demografii historycznej zorientowanej na badanie postaw prokreacyjnych par małżeńskich ${ }^{3}$, niejako programowo zwróciły zainteresowanie zarówno ku „historii zwykłych zjadaczy chleba” (ich doświadczeń i sposobów życia), jak i ku wszystkim innym grupom, do tej pory marginalizowanym w studiach, w tym przede wszystkim na życie i pracę kobiet. W wielu krajach Zachodu lata siedemdziesiąte i osiemdziesiąte XX w. charakteryzowały się dynamicznym wkroczeniem na katedry uniwersyteckie historii kobiet, poszerzonej o problematykę płci (gender), jako kategorii społeczno-historycznej i kulturowej. Powoływano specjalistyczne zespoły badawcze, zakładano nowe czasopisma (np. „Women Studies” i „Signs” w USA,

$1 \quad$ Szerzej na ten temat pisał C. Kuklo, Kobieta samotna w spoteczeństwie miejskim u schytku Rzeczypospolitej szlacheckiej. Studium demograficzno-spoteczne, Białystok 1998, s. 18-21. Początek badań nad historią kobiet, niewolny od sporów metodologicznych, w nauce francuskiej scharakteryzował F. Thébaud, Tworzenie historii kobiet we Francji. Rys historiograficzny, spory metodologiczne, relacje z instytucjami naukowymi i politycznymi, „Kwartalnik Historyczny” 2001, t. CVIII, nr 3, s. 81-98.

2 Vide: M. Perrot, Mon histoire des femmes, Paris 2006, s. 22-23 (wersja polskojęzyczna: Moja historia kobiet, przekł. M. Szafrańska-Brandt, Kraków 2009).

3 Inspirującą rolę w tym zakresie odegrał tom „Annales de Démographie Historique” za rok 1981, który w całości został poświęcony problematyce demograficznych losów kobiecych. 
„Pénélope” i „CLIO. Histoire, femmes et sociétés” we Francji, „Gender and History” w Anglii oraz „L'Homme. Zeitschrift für Feministische Geschichtswissenschaft” w Austrii), co skutkowało szybkim przyrostem publikacji. W skali światowej bez przesady można powiedzieć, że historia doświadczeń kobiet na różnych polach aktywności społeczno-gospodarczej i politycznej, w szerokim rozumieniu znaczenia tego słowa, jako nowy kierunek badawczy była i jest obecna nie tylko na dziesiątkach konferencji, lecz także na międzynarodowych kongresach historii powszechnej4.

Badania prowadzone $\mathrm{w}$ wielu krajach świata nad miejscem kobiet $\mathrm{w}$ historii, feminizmem i gender mają obecnie szeroki zasięg i charakteryzują się już wręcz lawinowym przyrostem literatury, który praktycznie uniemożliwia pojedynczemu badaczowi dokładniejszą orientację w stanie badań w poszczególnych krajach lub w grupie państw. Jednakże ma ona, co istotne, bardzo zróżnicowaną wartość poznawczą. Niemniej warto także zasygnalizować pojawienie się na rynku pierwszych prac o ambicjach syntez historii kobiet w skali Starego Kontynentu (w większości ograniczone tylko do jego części zachodniej), będących rezultatem wysiłku uogólniającego i uprzystępniającego rezultaty badaczy z różnych krajów ${ }^{5}$.

Początek szerszego zainteresowania historią kobiet w Polsce przypada dopiero na drugą połowę lat osiemdziesiątych XX w. U jego podłoża legły, z jednej strony, studia $\mathrm{z}$ interesującym kwestionariuszem badawczym nad historią gospodarczą wczesnonowożytnych rodzin miejskich (Maria Bogucka, Andrzej Wyrobisz, Andrzej Karpiński) ${ }^{6}$ i wiejskich (Andrzej Wyczański) ${ }^{7}$, akcentujące rolę pracy zawodowej kobiet (wykonywanej nie tylko w ramach rodzinnego podziału pracy), oraz nowocześnie realizowane analizy postaw prokreacyjnych par małżeńskich i okoliczności przyjmowania przez kobiety dominującej roli w gospodarstwie domowym (Cezary Kuklo) ${ }^{8}$. Z drugiej strony

4 Vide programy dwóch ostatnich Międzynarodowych Kongresów Nauk Historycznych organizowanych przez International Committee of Historical Sciences (ICHS) w Amsterdamie w 2010 r. i w Jinan w $2015 \mathrm{r}$.

5 Histoire desfemmes en Occident, éd. G. Duby, M. Perrot, t. I-V, Paris 1991-1992; H. Wunder, „Er ist die Sonn', sie ist der Mond". Frauen in der Frühen Neuzeit, München 1992; M.E. Wiesner, Women and Gender in Early Modern Europe, Cambridge 1993; O. Hufton, The Prospect Before Her: A History of Women in Western Europe, vol. I (1500-1800), New York 1995; The Routledge History of Women in Early Modern Europe, ed. A.L. Capern, New York 2006. Ujęć syntetycznych zarówno w długim trwaniu, jak i w poszczególnych epokach doczekały się także kobiety w poszczególnych krajach, jednakże przywołanie nawet części z bogatej listy wspomnianych prac przekracza ramy tego opracowania.

6 M. Bogucka, Rodzina w polskim mieście XVI-XVII w. Wprowadzenie w problematykę, „Przegląd Historyczny” 1983, t. LXXIV, z. 3, s. 495-507; oraz A. Wyrobisz, Rodzina w mieście doby przedprzemystowej a życie gospodarcze. Przeglad badań i problemów, „Przegląd Historyczny” 1986, t. LXXVII, z. 2, s. 305-330; A. Karpiński, Kobieta w mieściepolskim w drugiejpotowie XVI i w XVII wieku, Warszawa 1995.

7 A. Wyczański, Kobiety - kierowniczki folwarków w starostwie sieradzkim w XVI w., „Zapiski Historyczne” 1976, t. XLI, z. 3, s. 41-49; A. Wyczański, A. Wyrobisz, La famille et la vie économique, „Studia Historiae Oeconomicae" 1983 (1985), t. XVIII, s. 56-68.

8 C. Kuklo, Rodzina w osiemnastowiecznej Warszawie, Białystok 1991. W tomie prac polskich badaczy przygotowanym z myślą o XVIII Międzynarodowym Kongresie Nauk Historycznych w Montrealu 
rosnące zainteresowanie przemianami społecznymi w XIX i na początku XX stulecia na ziemiach polskich zmuszały badaczy do stawiania pytań o trwałość statusu ekonomiczno-społecznego kobiety, o jej aktywność zarobkową i zawodową na poszerzającym się rynku pracy w okresie wzmożonej industrializacji i nowoczesnej urbanizacji. Doprowadziło to do powstania w końcu lat osiemdziesiątych ubiegłego stulecia w Instytucie Historycznym Uniwersytetu Warszawskiego Zespołu Badawczego Historii Społecznej Polski XIX i XX Wieku, kierowanego przez Annę Żarnowską, mocno ukierunkowanego na poznawanie historii kobiecej części społeczeństwa' ${ }^{9}$. Owocem jego pracy były liczne tematyczne konferencje, których dorobek zawiera dziewięć tomów, zredagowanych przez Annę Żarnowską i Andrzeja Szwarca w latach 1990-2006 ${ }^{10}$.

$\mathrm{Na}$ poszerzenie i pogłębienie oraz postępujące upowszechnianie problematyki kobiecej w rodzimej historiografii wpłynęły też sympozja zorganizowane w latach dziewięćdziesiątych XX w. w ramach Powszechnych Zjazdów Historyków Polskich w Gdańsku (1994) ${ }^{11}$ i we Wrocławiu (1999) ${ }^{12}$. Cieszyły się one nadzwyczaj dużym zainteresowaniem uczestników. Swoistym wyrazem dostrzeżenia w naszym kraju rangi badań poświęconych dziejom kobiet i kulturowej problematyce płci było powołanie przez Komitet Nauk Historycznych Polskiej Akademii Nauk (PAN) w 1996 r. Komisji Historii Kobiet pod przewodnictwem Anny Żarnowskiej.

Schyłek lat dziewięćdziesiątych ubiegłego stulecia i pierwsza dekada nowego charakteryzowały się rozbudową tematyczną studiów kobiecych (np. religijność, mentalność, dokonania artystyczne i intelektualne, czas wolny) i szybko postępującym przyrostem literatury, choć zdecydowanie najszybszym dla okresu porozbiorowego i najsłabszym dla średniowiecza. Powodzenie nowego kierunku badań i szybko zwiększająca się lista opublikowanych prac, przeważnie artykułów i szkiców, rzadziej książek i gruntownych rozpraw, zrodziły w środowisku idę̨ opracowania syntezy dziejów kobiet na ziemiach polskich. Wstępem do jej przygotowania - zarówno samej koncepcji oraz zawartości merytorycznej, jak i ram chronologicznych - było sympozjum naukowe zorganizowane w Warszawie w lutym 2010 r. pod auspicjami wspomnianej Komisji Historii Kobiet Komitetu Nauk Historycznych PAN. Wygłoszone referaty:

w 1995 r. znalazł się artykuł C. Kukli, Single Women in Pre-Industrial Towns as a Subject of Historical Research, [w:] Society and Culture Poland in Europe. Studies in Social and Cultural History. Poland at the 18-th International Congress of Historical Sciences in Montreal, ed. M. Bogucka, Warszawa 1995, s. $112-123$.

$9 \quad \mathrm{Na}$ inspirującą rolę Anny Żarnowskiej w uprawianiu w naszym kraju historii kobiet powiązanej z historią społeczną i historią kultury zwrócili uwagę M. Nietyksza i M. Wierzbicka, Profesor Anna Żarnowska - gtówne nurty badań, [w:] A. Żarnowska, Kobieta i rodzina w przestrzeni wielkomiejskiej na ziemiach polskich w XIX i XX wieku, red. A. Janiak-Jasińska, K. Sierakowska, A. Szwarc, Warszawa 2013, s. XIV-XX.

10 Ibidem, s. XIV. Doczekały się one licznych recenzji (vide: ibidem, s. XXXII-XXXIX).

11 Pamiętnik XV Powszechnego Zjazdu Historyków Polskich, t. II (Przemiany spoteczne a model rodziny), red. A. Żarnowska, Gdańsk-Toruń 1995.

12 Przetomy w historii. XVI Powszechny Zjazd Historyków Polskich, Wroctaw 15-19 września 1999 r. Pamiętnik, red. K. Ruchniewicz, J. Tyszkiewicz, W. Wrzesiński, t. III, cz. 4, Toruń 2001. 
w układzie chronologicznym, od średniowiecza po schyłek Polskiej Rzeczpospolitej Ludowej, zawierały przegląd badań w poszczególnych epokach, sygnalizując również obszary wymagające podjęcia intensywniejszych studiów. Z kolei żywa dyskusja ujawniła podziały i rozdźwięki w kontekście przyszłego przedstawiania dziejów kobiet, których podłożem - moim zdaniem - jest przede wszystkim przyjęta metodologia (np. na ile płeć kulturowa może być narzędziem analizy historycznej w rodzimych studiach?). Materiały z tego bezsprzecznie ważnego warsztatu (panelu) zostały opublikowane dopiero cztery lata później, i to dzięki usilnym staraniom Krzysztofa A. Makowskiego ${ }^{13}$.

We wspomnianym tomie obszernego omówienia stanu badań nad dziejami kobiet w Polsce we wczesnej epoce nowożytnej dokonała kompetentnie Małgorzata Karpińska ${ }^{14}$. Siłą rzeczy uwagę skupiła na pracach wydanych głównie do końca pierwszej dekady XXI w. Dlatego celem mojego artykułu będzie próba oceny dorobku historiografii kobiecej powstałego w minionym dziesięcioleciu (2011-2020), która jak zawsze jest sprawą dyskusyjną. Należy dodać, że mocno rozproszona sieć wydawców w połączeniu z wolnym tempem przygotowywania Bibliografii historii Polski nie ułatwia wykonania zadania, dlatego być może nie zawsze dostatecznie zaakcentuję całość badań poszczególnych autorów.

\section{Wydawnictwa źródłowe}

Moje uwagi chciałem rozpocząć od zorientowania czytelnika w przyroście publikacji w ostatnim dziesięcioleciu, co jednak okazało się niemożliwe do zrealizowania, gdyż podstawowe dzieło bibliograficzne nie wyróżnia jako osobnego działu historii kobiet. Ponadto w polu zainteresowań części autorów, co mogłem zaobserwować, czytając dokładniej treść większości prac, znajdują się kobiety, których występowanie na kartach rozpraw, artykułów i esejów nie zostało zasygnalizowane w ich tytułach. Wszystko to razem sprawia, że przygotowane zestawienie danych miałoby charakter mocno arbitralny i w gruncie rzeczy jednak mylący. Omówienie zatem zaczynam od krótkiego przeglądu poświęconych kobietom w XVI-XVIII w. wydawnictw źródłowych, które także w pewien sposób wpływają na intensywność badań historycznych. W tej grupie znajdują się zarówno całe tomy skreślone kobiecą ręką (np. pamiętniki), jak i tylko wybory źródeł odnoszące się do aktywności społecznej kobiet (np. testamenty).

Pamiętniki, diariusze i dzienniki podróży napisane przez kobiety stanowią ważną grupę wydawnictw źródłowych. Dodam tylko, że zainteresowanie literaturą pamiętnikarską, bez względu na epoki i mody badawcze, jest spore, a co więcej, ich odbiorcami nie są jedynie zawodowi badacze, lecz także liczni miłośnicy Klio. Na uwagę

Dzieje kobiet w Polsce. Dyskusja wokót przysztej syntezy, red. K.A. Makowski, Poznań 2014.

14 M. Karpińska, Badania dziejów kobiet w Polsce w epoce nowożytnej (wiek XVI-XVIII), [w:] ibidem, s. 53-74. Vide też podsumowanie wcześniejszego etapu polskich badań nad historią kobiet autorstwa A. Żarnowskiej, Studia nad dziejami kobiet w dzisiejszej historiografii polskiej, „Kwartalnik Historyczny" 2001, t. CVIII, nr 3, s. 99-116. 
zasługuje dziennik księżnej Izabeli z Flemmingów Czartoryskiej, żony Adama Kazimierza, znanej działaczki kulturalnej i kolekcjonerki, z jej wyprawy do Anglii i Szkocji u schyłku XVIII w. ${ }^{15}$ Edycji doczekał się również inny dziennik podróży, mianowicie Katarzyny z Sosnowskich Platerowej, żony Józefa Wincentego, pani na Horynce na Wołyniu, zwiedzającej Półwysep Apeniński w połowie lat osiemdziesiątych XVIII w. ${ }^{16}$ Podobnie jak poprzedni, jest on pełen opisów poznawanych miejsc i zabytków oraz refleksji na temat wyglądu zwyczajów mieszkańców południa Europy. Ciekawym przekazem źródłowym okazał się też pamiętnik z lat szkolnej edukacji zagranicznej Apolonii Heleny Massalskiej, najmłodszej latorośli Antoniny z Radziwiłłów i Józefa Adriana Massalskiego, podskarbiego nadwornego litewskiego. Pamiętnik ten został wydany dwukrotnie, najpierw w tłumaczeniu z języka francuskiego, a następnie w wersji oryginalnej $^{17}$. Przedwcześnie osieroconą dziewczynką zaopiekował się brat ojca, Ignacy Massalski, biskup wileński, który w 1771 r. ośmioletnią bratanicę umieścił na pensji w klasztorze w Abbay-aux-Bois w Paryżu. Sam pamiętnik pisany - co warto podkreślić - ręką dziecka, miejscami zatem trochę naiwny, jest bogatym źródłem informacji o przebiegu samej edukacji młodych magnatek, jak również o sposobach spędzania przez nie czasu wolnego, zabawach i nierzadko niełatwych relacjach międzyludzkich.

Wśród wydawnictw zawierających staropolską spuściznę epistolograficzną uwagę przykuwają trzy opasłe tomy korespondencji innej magnatki, Elżbiety z Lubomirskich Sieniawskiej. Zostały one starannie przygotowane do druku przez zespół pod kierunkiem Bożeny Popiołek, znawczyni kasztelanowej krakowskiej ${ }^{18}$. Publikacja jest tym cenniejsza, że nie została ograniczona, jak to często wcześniej bywało, jedynie do korespondencji małżonków, pozwalającej śledzić zmienność relacji małżeńskich (z osobistymi ambicjami i dbaniem o własne interesy włącznie) w trwającym ponad 30 lat związku, lecz jej integralną część stanowią również listy wymieniane przez bohaterkę z urzędnikami, oficjalistami dworskimi, krewnymi, przyjaciółmi i klientami prowadzącymi z nią interesy handlowe. Całość edycji ukazuje postać kasztelanowej krakowskiej nie tylko jako wytrawnego i czynnego uczestnika wielu ówczesnych gier politycznych, lecz także jako jednej z najbogatszych kobiet w Rzeczypospolitej szlacheckiej, prowadzącej przemyślaną politykę ekonomiczną i mocno zaangażowanej we wszechstronny

15 I. Czartoryska z Flemmingów, Podróż po Anglii. Dziennik z podróży po Anglii i Szkocji w roku 1790, oprac. i wprowadzenie A. Whelan, przekł. z jęz. franc. Z. Żygulski, A. Whelan, Warszawa 2015.

16 K. z Sosnowskich Platerowa, Moja podróż do Wtoch. Dziennik z lat 1785-1786, wstęp i oprac. M.E. Kowalczyk, przekł. z jęz. franc. A. Pikor-Półtorak, Łomianki 2013.

17 A.H. Massalska, Pamiętniki pensjonarki. Zapiski z czasów edukacji w Paryżu (1771-1779), wstęp i oprac. M.E. Kowalczyk, przekł. z jęz. franc. A. Pikor-Półtorak, Kraków 2012; eadem, Mémoires d’une écolière à l Abbaye-aux-Bois à Paris (1771-1779), éd. M.E. Kowalczyk, A. Locher, Mielec 2014.

18 Korespondencja Elżbiety z Lubomirskich Sieniawskiej kasztelanowej krakowskiej, oprac. i wyd. B. Popiołek, U. Kicińska, A. Słaby, t. I (Z serca kochajaca żona i uniżona stuga. Listy Elżbiety z Lubomirskich Sieniawskiej do męża Adama Mikotaja Sieniawskiego z lat 1688-1726); t. II (Jaśnie Oświecona Mościa Księżno Dobrodziejko. Informatorzy i urzędnicy); t. III (Jaśnie Oświecona Mościa Księżno Dobrodziejko. Rodzina, przyjaciele i klienci), Warszawa-Bellerive-sur-Allier 2016. 
rozwój gospodarczy poszczególnych majątków. Dopełnieniem wspomnianego wydawnictwa jest tom listów redaktora gazet rękopiśmiennych, Jakuba Kazimierza Rubinkowskiego, adresowanych do Sieniawskiej, wydany przez Kazimierza Maliszewskiego i Adama Kucharskiego ${ }^{19}$.

Równie starannie została przygotowana, przez Iwonę Maciejewską i Katarzynę Zawilską, edycja korespondencji Magdaleny Czapskiej, córki Piotra Jana i Konstancji z Gnińskich, do Hieronima Floriana Radziwiłła, jednego z bardziej znaczących litewskich magnatów w XVIII w. ${ }^{20}$ Dodam tylko, że 156 listów Magdaleny pochodzi zarówno z okresu po sekretnym ślubie i małżeństwie z ekscentrycznym partnerem, znanym ze srogości i okrucieństw Hieronimem Florianem Radziwiłłem, jednym z najbogatszych magnatów Rzeczypospolitej w XVIII w., jak i z czasu starań o unieważnienie tego związku i już po rozwodzie.

Z przebogatej korespondencji familijnej innej wpływowej matrony czasów saskich, do których z całą pewnością zaliczała się Anna Katarzyna z Sanguszków Radziwiłłowa, kanclerzyna wielka litewska, została jak dotąd wydana tylko niewielka jej część za sprawą Jerzego Dygdały ${ }^{21}$. Na sumiennych wydawców czekają w kolejce nie mniej cenne i przebogate zbiory korespondencji kobiecej autorstwa np. Anny Franciszki z Gnińskich Zamoyskiej, podskarbiny wielkiej koronnej i ordynatowej zamojskiej, a także Konstancji z Tarłów Mniszchowej, marszałkowej wielkiej koronnej oraz innych kobiet.

Cennym wydawnictwem źródłowym ukazującym rolę społeczno-ekonomiczną kobiet, relacje społeczne w obrębie rodziny i poza nią, a także ich mentalność (z dobroczynnością włącznie) i duchowość religijną są zawsze akty ostatniej woli, które ostatnio cieszą się coraz większą popularnością w warsztacie badawczym historyka. Przede wszystkim należy odnotować trzytomowy zbiór testamentów szlacheckich zaczerpniętych przez Pawła Klinta z ksiąg grodzkich wielkopolskich z lat 1631-170022. Wprawdzie większość z opublikowanych aktów ostatniej woli była dziełem mężczyzn:

19 Listy Jakuba Kazimierza Rubinkowskiego do Elżbiety z Lubomirskich Sieniawskiej (1716-1726), oprac. K. Maliszewski, A. Kucharski, Toruń 2017.

20 „Gdybym Cię, moje Serce, za męża nie miata, żyć bym nie mogta”. Listy Magdaleny z Czapskich do Hieronima Floriana Radziwitta z lat 1744-1759, wstęp i oprac. I. Maciejewska, K. Zawilska, Olsztyn 2016; vide recenzję M. Tomaszewskiego, „Czasy Nowożytne” 2018, t. XXXI, s. 359-363.

21 Codzienne ktopoty, wielkie interesy i podwójna elekcja. Korespondencja radziwittowskich urzędników z księżna Anna z Sanguszków Radziwittową i jej synem Michatem Kazimierzem 1733/1734, wyd. J. Dygdała, Warszawa 2013. Vide recenzję J. Wijaczki, „Czasy Nowożytne” 2013, t. XXVI, s. 245-247.

22 Testamenty szlacheckie $z$ ksiag grodzkich wielkopolskich z lat 1631-1655, wyd. P. Klint, Wrocław 2008; Testamenty szlacheckie z ksiag grodzkich wielkopolskich z lat 1657-1680, wyd. idem, Wrocław 2011; Testamenty szlacheckie z ksiag grodzkich wielkopolskich z lat 1681-1700, wyd. idem, Wrocław 2015. Nie odnoszę się tutaj do wydawanych pojedynczo testamentów przedstawicieli różnych grup społecznych, np.: B. Popiołek, Testament Magdaleny z Tartów Lubomirskiej, wojewodziny krakowskiej, „Krakowskie Studia Małopolskie" 2013, nr 18, s. 423-433; K. Łopatecki, M. Kupczewska, Testament Izabeli z Poniatowksich Branickiej (3 XI 1805 r.), „Kwartalnik Historii Kultury Materialnej” 2016, t. LXIV, nr 1, s. 103-109; Testament mieszczanki żarnowskiej Agnieszki Frejeckiej z 1755 r., wyd. S. Kazusek, „Między Wisłą a Pilicą. Studia i materiały historyczne” 2014, t. XV, s. 127-135. 
280 (1657-1700), cennych badawczo w poznaniu historii rodziny szlacheckiej, to jednak 105 dokumentów było podanych do ksiąg sądowych przez reprezentantki wspomnianej grupy społecznej. Badania nad mentalnością, pobożnością i obyczajowością szlachcianek z terenu Prus Królewskich ułatwia edycja testamentów przygotowana przez Jacka Kowalkowskiego i Wiesława Nowosada ${ }^{23}$. Wartość badawczą zachowują także inne wydane niedawno zbiory testamentów: mieszczan z wczesnej epoki nowożytnej, opracowane przez Ewę Danowską i Katarzynę Justyniarską-Chojak ${ }^{24}$, oraz chłopów, wydane przez Janusza Łossowskiego ${ }^{25}$, choć sam udział rozporządzeń ostatniej woli podyktowanych przez kobiety jest w tym wypadku skromniejszy. Wobec szczupłości zachowanych źródeł do dziejów chłopów w Rzeczypospolitej szlacheckiej tym bardziej należy podkreślić wprowadzanie do obiegu naukowego przez lubelskiego historyka pokaźnego zbioru 80 tekstów ostatniej dyspozycji dokonanych przez chłopskie testatorki z terenu Korony ${ }^{26}$.

Wydano również wybór aktów ostatniej woli książąt Lubartowiczów-Sanguszków, a w 2014 r. ukazało się drugie, uzupełnione o dodatkowe dokumenty wydanie testamentów litewskich ewangelików reformowanych przygotowane przez Urszulę Augustyniak. Nie zabrakło wśród nich aktów ostatniej woli najznamienitszych reprezentantek kręgów magnackich: Anny Marii Radziwiłłowej, koniuszyny litewskiej, Katarzyny z Radziwiłłów Hlebowiczowej, wojewodziny wileńskiej, i Katarzyny z Oborskich Grabowskiej, stolnikowej witebskiej ${ }^{27}$.

Pozostając przy testamentach, warto bezsprzecznie odnotować pojawienie się w bibliotece podręcznej historyka ważnej pomocy. Stanowią je katalogi testamentów, a dokładniej mieszkańców miast Rzeczypospolitej przedrozbiorowej, sporządzone pod opieką i kierownictwem naukowym Urszuli Augustyniak. Jak dotąd opublikowano siedem tomów dotyczących Wilna, Brześcia, Grodna, Lwowa, Krakowa i Poznania oraz miast Wołynia i małych miast polskich ${ }^{28}$. Nie ulega wątpliwości, że wzmiankowane

23 Testamenty szlachty Prus Królewskich z XVII wieku, wyd. J. Kowalkowski, W. Nowosad, Warszawa 2013; Testamenty szlachty Prus Królewskich z XVIII wieku, wyd. eorundem, Warszawa 2016.

24 Dtug śmiertelności wyptacić potrzeba. Wybór testamentów mieszczan krakowskich z XVII-XVIII wieku, oprac. E. Danowska, Kraków 2011; „Wszyscy śmiertelni jesteśmy i dlatego rozrządzamy majętności swoje”. Wybór testamentów z ksiag miejskich województwa sandomierskiego (XVI-XVIII wiek), oprac. K. Justyniarska-Chojak, Kielce 2014.

25 Testamenty chtopów polskich od drugiej potowy XVI do XVIII wieku, oprac. i wyd. J. Łossowski, Lublin 2015.

26 W tomie znalazł się także jeden dokument sporządzony przez obojga małżonków, Piotra i Marię Jakimców z Czukwi. Vide: ibidem, s. 54-55.

27 Testamenty książą Lubartowiczów-Sanguszków. Wybór tekstów źródtowych z lat 1750-1876, oprac. J.M. Marszalska, W. Graczyk, Kraków 2011; U. Augustyniak, Testamenty ewangelików reformowanych w Wielkim Księstwie Litewskim w XVI-XVIII wieku, Warszawa 2014.

28 Katalogi testamentów mieszkańców miast z terenów Korony i Wielkiego księstwa Litewskiego do 1795 roku, Warszawa 2017: t. I (Testamenty w ksiegach miejskich wileńskich z XVI-XVII wieku. Katalog), oprac. K. Frejlich; t. II (Testamenty mieszkańców miast Wotynia od końca XVI - do początku XVIII wieku. Katalog), oprac. N. Biłous; t. III (Katalog testamentów mieszkańców Brześcia i Grodna od XVI do 
katalogi, w których nie brakuje rozporządzeń mieszczanek na wypadek śmierci, powinny się przyczynić do zintensyfikowania badań nad historią kobiet w miastach staropolskich na wielu płaszczyznach, jak chociażby ich położenia prawnego, miejsca i funkcji kobiety w rodzinie mieszczańskiej, w tym kształtowania drogi przyszłej kariery społeczno-zawodowej, strategii matrymonialnej zarówno swoich dzieci, jak i krewnych przez stosowane zapisy, a także roli, jaką odgrywały w gospodarce ośrodka miejskiego oraz w działalności dobroczynnej i religijnej.

Osobno trzeba wymienić starannie wydany przez Małgorzatę Ciszewską tom z tekstami świeckich oracji powstałych $\mathrm{w}$ środowisku szlacheckim $\mathrm{z}$ okazji uroczystości związanych z rocznym cyklem liturgicznym i z codziennym życiem domowym oraz sąsiedzkim tej grupy społecznej (chrzcin, pogrzebów i wesel). Umożliwia on poszerzenie dotychczasowych studiów nad życiem codziennym i obyczajowością w okresie staropolskim $^{29}$. Zamieszczone w tomie teksty wydawczyni poprzedziła obszerną charakterystyką okolicznościowych wypowiedzi odnoszących się do wydarzeń biologicznego cyklu życia - od narodzin do śmierci, w tym mów obłóczynnych z okazji wstąpienia przez kobietę do stanu duchownego, którego obrzęd było paralelny do weselnego.

Ostatnio również, za sprawą Doroty Żołądź-Strzelczyk i Małgorzaty E. Kowalczyk, uzyskaliśmy wgląd wprawdzie w nieliczne, ale tym bardziej cenne treści tekstów pouczeń i wskazówek wychowawczych pisanych z myślą o edukacji zamożnych szlachcianek, sporządzonych przez ich ojców, oraz kilkanaście instrukcji napisanych przez matki (i jedną babkę - Barbarę z Duninów Sanguszkową) w związku z edukacyjnymi podróżami ich synów ${ }^{30}$.

Nowe wydawnictwa źródłowe wydane w drugim dziesięcioleciu XXI w. stanowią w sumie dorobek pokaźny i mają niewątpliwie dużą wartość poznawczą.

\section{Monografie}

Przegląd monograficznych osiągnięć historiografii kobiecej minionego dziesięciolecia chcę przedstawić w trzech umownych, rozbudowanych blokach tematycznych: 1 - kobiety w rodzinie i poza nią (ciało, seksualność, miłość i emocje oraz relacje

początku XVIII wieku), oprac. N. Sliž; t. IV (Testamenty mieszkańców lwowskich z drugiej potowy XVI i $z$ XVII wieku. Katalog), oprac. O. Winnyczenko; t. V (Testamenty $z$ ksiag sadowych matych miast polskich do 1525 roku), oprac. A. Bartoszewicz; t. VI (Katalog testamentów z krakowskich ksiag miejskich do 1550 roku), oprac. J. Wysmułek; t. VII (Katalog testamentów poznańskich z drugiej potowy XVI i z XVII wieku), oprac. A. Karpiński. Vide obszerną recenzję całości edycji pióra Ł. Gołaszewskiego, "Czasopismo Prawno-Historyczne” 2019, t. LXXI, z. 2, s. 335-349.

29 M. Ciszewska, Tuliusz domowy. Świeckie oratorstwo szlacheckie kręu rodzinnego (XVII-XVIII wieku), Warszawa 2016.

30 Ojcowskie synom przestrogi. Instrukcje rodzicielskie (XVI-XVII w.), wstęp i objaśnienia D. Żołądź-Strzelczyk, M.E. Kowalczyk, Wrocław 2017; Przestrogi i nauki dla dzieci. Instrukcje rodzicielskie (XVIII w.), wstęp i objaśnienia eorundem, Wrocław 2017. 
wewnątrzrodzinne); $\mathbf{2}$ - ich edukacja i wiedza, praca w miastach i na wsi oraz konflikty z prawem; 3 - udział kobiet w polityce, kulturze i religii.

1. Przegląd zaczynam od zwrócenia uwagi na problematykę najsłabiej do tej pory obecną w rodzimych studiach, co nie umknęło uwadze Małgorzaty Karpińskiej, która stwierdziła: „Niezbadany lub ledwie poruszony pozostaje cały katalog spraw dotyczących w okresie nowożytnym seksualności kobiety, jej cielesności czy fizjologii...”31. Trzeba krytycznie przyznać, że nie otrzymaliśmy jak dotąd całościowej monografii ani chociażby szerszych studiów na ten temat, chociaż powstały pomniejsze opracowania i przyczynki. Jedną z bardziej wartościowych prac podejmujących zagadnienie seksualności mieszkańców dawnej Rzeczypospolitej, choć ograniczoną tylko do jednej grupy społecznej: chłopów, jest książka Tomasza Wiślicza ${ }^{32}$. Z analiz źródeł wyłonił się obraz społeczności wiejskiej dobrze zorientowanej zarówno w przedmałżeńskim, jak i w małżeńskim pożyciu płciowym, z różnymi technikami seksualnymi i stosowaniem środków poronnych włącznie. Nie brakowało też wśród chłopów zainteresowania nagością, cielesną atrakcyjnością partnera, a przeciętna młoda dziewka służebna nie czuła skrępowania, wypowiadając się na temat płciowości ${ }^{33}$.

$\mathrm{Na}$ osobną uwagę zasługuje książka Iwony Maciejewskiej, która odkrywa piśmiennictwo epoki saskiej, powstałe także z udziałem kobiet (Elżbieta Drużbacka, Franciszka Urszula Radziwiłłowa, Anna z Mycielskich Radziwiłłowa, Regina Salomea z Rusieckich Pilsztynowa, Barbara z Duninów Sanguszkowa, Franciszka Urszula Radziwiłłowa), wyrażające uczucie miłości i erotyzm ${ }^{34}$. Już tylko na marginesie zauważam szerszą obecność kobiecego ciała, jego fizjologii i ludzkich naturalnych popędów w pracach historyków literatury staropolskiej35.

Zdecydowanie lepiej, co pragnę podkreślić, rozwijały się ostatnio badania podejmujące dokładniejsze określenie statusu kobiety w rodzinie i społeczeństwie, rozpatrywane

31 M. Karpińska, op. cit., s. 74.

32 T. Wiślicz, Upodobanie. Matżensstwo i zwiazki nieformalne na wsi polskiej XVII-XVIII wieku. Wyobrażenia spoteczne i jednostkowe doświadczenia, Wrocław 2012.

33 Ibidem, s. 77-82. Vide też: T. Wiślicz, Wiejskie zaloty w Polsce XVII-XVIII wieku. Sposoby doboru partnera seksualnego i kryteria atrakcyjności w środowisku chtopskim Rzeczypospolitej w okresie „przedetnograficznym”, „Studia Historica Gedanensia” 2012, t. III (Historia flirtu), red. P. Perkowski, s. 37-57. Cf. także obszerną recenzję całego tomu A. Szwarca, Flirt jako przedmiot badań historycznych, „Przegląd Historyczny" 2014, t. CV, z. 1, s. 121-128.

34 I. Maciejewska, Mitość i erotyzm w piśmiennictwie czasów saskich, Olsztyn 2013.

35 Tylko tytułem przykładu: R. Grześkowiak, Amor curiosum. Studia o osobliwych tematach dawnej poezji erotycznej, Warszawa 2013; idem, O dupie Maryni. Rozwiązyanie „Gadki”Jana Kochanowskiego, „Odrodzenie i Reformacja w Polsce” 2016, t. LX, s. 111-141. Polemicznie, jakoby rozwiązaniem Gadki Jana Kochanowskiego miała być kobieca wagina, vide: K. Obremski, Glosa polemiczna do Radostawa Grześkowiaka „Rozwiązywania »Gadki« Jana Kochanowskiego”, „Odrodzenie i Reformacja w Polsce” 2017, t. LXI, s. 303-306. Skromnie też rysuje się obraz zarobkowych zachowań seksualnych kobiet w epoce staropolskiej zawartych w tomie Mitość sprzedajna, red. B. Płonka-Syroka, K. Marchel, A. Syroka, Wrocław 2014. 
poprzez kwestie prawne, materialne i demograficzne, uwzględniające zarazem „strategie małżeńskie", widoczne nie tylko w rodzinach elity szlacheckiej i mieszczańskiej, lecz także wśród chłopów.

Powszechniejsze zainteresowanie historią kobiet (i rodziny) zwróciło baczniejszą uwagę naszej historiografii na jej położenie w uregulowaniach prawnych, zarówno w Koronie, jak i na Litwie, a także na ich obecność w sądach nie tylko w roli skarżących, lecz także oskarżanych. Pozycja kobiety w osobowym prawie małżeńskim Kościoła katolickiego i Cerkwi prawosławnej, jak również w protestantyzmie i religii żydowskiej, oraz przepisy prawa ziemskiego, miejskiego i wiejskiego w zakresie powstawania rodziny, jej trwania i rozpadu, w zależności od jej stanu cywilnego, doczekała się syntetycznej charakterystyki Jacka Pielasa ${ }^{36}$. Autor wykorzystał zarówno prace starsze, jak i nowsze, w tym powstałe w omawianym przez nas okresie, autorstwa m.in. Małgorzaty Delimaty, Ewy Dubas-Urwanowicz, Katarzyny Justyniarskiej-Chojak, Małgorzaty Kołacz-Chmiel, Marzeny Liedke, Beaty Wojciechowskiej ${ }^{37}$ oraz wiele własnych opracowann ${ }^{38}$.

Podstawą funkcjonowania najmniejszej komórki społecznej było legalnie zawarte małżeństwo, które zazwyczaj poprzedzały mniej lub bardziej skomplikowane rozmowy i negocjacje obu zainteresowanych rodzin. Rozszerzenie dotychczasowych ustaleń badawczych dotyczących okoliczności zawierania małżeństw w kręgu szlacheckim zawiera interesujące studium Anny Penkały poświęcone uposażeniu córek wydawanych za mąż lub idących do wspólnot zakonnych w województwie krakowskim w czasach saskich $^{39}$. Zostało ono oparte na sumiennej eksploracji bogatej dokumentacji źródłowej,

36 J. Pielas, Państwo, religia, prawo i rodzina, [w:] Rodzina i jej gospodarstwo na ziemiach polskich w geografii europejskich struktur rodzinnych do potowy XX wieku, red. P. Guzowski, C. Kuklo, Białystok 2019, s. 19-37.

37 M. Delimata, Prawo rodzinne w pracach Barttomieja Groickiego (okoto 1534-1606), [w:] Spoteczeństwo staropolskie. Seria nowa, t. III (Spoteczeństwo a rodzina), red. A. Karpiński, Warszawa 2011, s. 21-36; E. Dubas-Urwanowicz, O prawie w świecie kobiet w Rzeczypospolitej w XVI-XVII wieku, [w:] Kobieta i mężczyzna: jedna przestrzeń - dwa światy, red. B. Popiołek, A. Chłosta-Sikorska, M. Gadocha, Warszawa 2015, s. 51-72; K. Justyniarska-Chojak, Dziecko w rodzinie mieszczańskiej w XVI-XVIII wieku $w$ świetle przepisów prawa magdeburskiego (pomiędzy norma a praktyka), [w:] Dzieciństwo i starość w ujęciu historyków, red. A. Obara-Pawłowska, M. Kołacz-Chmiel, Lublin 2016, s. 243-266; M. Kołacz-Chmiel, Nieletni pochodzenia chtopskiego w praktyce sądów kościelnych w późnośredniowiecznej Matopolsce, [w:] ibidem, s. 207-226; M. Liedke, Uwagi o wieku uprawniajacym do zawarcia matżeństwa w Wielkim Księstwie Litewskim w XVI-XVIII wieku, „Przeszłość Demograficzna Polski” 2013, t. XXXII, s. 7-24; B. Wojciechowska, Proles - fides - sacramentum. Matżeństwo w średniowiecznym prawie kanonicznym, [w:] Kobieta i mężczyzna..., s. 17-26; eadem, Matżeństwo w ustawodawstwie synodalnym Kościota polskiego w późnym średniowieczu, „Czasopismo Prawno-Historyczne” 2015, t. LXVII, nr 1, s. 21-29.

38 Cenne, a przy tym oparte na szerokiej kwerendzie źródłowej jest studium J. Pielasa, Podziaty majątkowe szlachty koronnej w XVII wieku, Kielce 2013. Z licznych późniejszych prac vide: idem, Opieka nad nieletnimi w Koronie w XVIII wieku, [w:] Dzieciństwo i starość..., s. 83-95.

39 A. Penkała, Panieńskie ochędóstwo. Kwestie posagowe i wienne w matżeństwach szlachty województwa krakowskiego w czasach saskich, Kraków 2016. 
m.in. ponad 300 intercyz przedślubnych, kwitacji posagów, regestrów wypraw panieńskich, spraw sądowych, korespondencji oraz innych aktów majątkowych, prawnych i prywatnych zarówno magnaterii, jak i bogatej szlachty, pieczołowicie wydobytych z zasobu archiwów w kraju i za granicą (Lwów, Wilno). Warto podkreślić bogaty kwestionariusz badawczy autorki, który bynajmniej nie został zawężony wyłącznie do sfery prawnej lub sytuacji rodzinnej. Młodą badaczkę interesowało wiele czynników, które mogły decydować o zapisach posagowych i wiennych na rzecz kobiet, jak chociażby kwestia zależności wysokości uposażeń od dzietności familii szlacheckiej albo między pozycją społeczną i sprawowanymi przez ojców urzędami a zakresem uposażenia ich córek.

Rozprawa Anny Penkały, podobnie jak studia Jacka Pielasa i Piotra Kitowskiego ${ }^{40}$, poprzez poznanie mechanizmu uposażania kobiet przez rodziców, braci i opiekunów przybliżają nie tylko podstawy gospodarcze funkcjonowania rodziny szlacheckiej, lecz także uwypuklają w niej pozycję majątkową kobiety. Mechanizmy zawierania małżeństw przez arystokrację w dawnej Rzeczypospolitej, a dokładniej w Wielkim Księstwie Litewskim we wczesnej epoce nowożytnej, szerzej scharakteryzowała Marzena Liedke $^{41}$. Autorka zwróciła uwagę na decydentów i czas dokonywania wyboru partnera życiowego (około $70 \%$ synów ożeniło się już po śmierci ojca), jak również na mocno ograniczoną w tym środowisku ofertę matrymonialną. W tym celu autorka posłużyła się nawet techniką symulowania danych demograficznych, której nie stosowano wcześniej w rodzimych badaniach (co warto podkreślić), a mianowicie specjalnie skonstruowanym modelem (osobno dla kobiet i mężczyzn) długości przebywania panien i kawalerów na rynku matrymonialnym ${ }^{42}$.

Z kolei o polityce małżeńskiej chłopów, z aspektami ekonomicznymi, kreowaną przez rodziców lub opiekunów, uwzględniającą pozycję dziewczyny w procesie kojarzenia małżeństwa, dowiadujemy się ze wspomnianej już książki Tomasza Wiślicza ${ }^{43}$.

Problematyka funkcjonowania małżeństwa i rodziny staropolskiej stanowi ogromne pole badawcze, a wachlarz zagadnień jest tu bardzo szeroki. Ostatnio dokonał się wyraźny postęp w zakresie poznania struktur demograficznych podstawowej komórki społecznej, bez względu na jej przynależność stanową ${ }^{44}$. Dzisiaj wiemy dużo więcej nie

40 J. Pielas, Majątkowe zabezpieczenie sióstr w szlacheckich dziatach spadkowych w Koronie w XVII wieku, [w:] Per mulierem... Kobieta $w$ dawnej Polsce - wśredniowieczu i dobie staropolskiej, red. K. Justyniarska-Chojniak, S. Konarska-Zimnicka, Warszawa 2012, s. 343-356; P. Kitowski, „Idac za wola Najwyższego Boga". Kontrakt ślubny w praktyce prawa ziemskiego Prus Królewskich (1598-1772), [w:] Dom. Codzienność i święto. Ceremonie i tradycje rodzinne. Studia historyczno-antropologiczne, red. B. Popiołek, A. Chłosta-Sikorska, M. Gadocha, Kraków 2018, s. 83-92.

${ }^{41}$ M. Liedke, Rodzina magnacka w Wielkim Księstwie Litewskim w XVI-XVIII wieku. Studium demograficzno-spoteczne, Białystok 2016.

42 Ibidem, s. 237-244.

43 T. Wiślicz, Upodobanie..., s. 111-151.

$44 \mathrm{Na}$ kluczową rolę analiz demograficznych w badaniach nad dziejami rodzin w przeszłości zwracał uwagę A. Wyrobisz, Rodzina w mieście..., s. 308. 
tylko o wieku zawierania małżeństw przez panny i kawalerów oraz osoby owdowiałe, w połączeniu ze zjawiskiem bezżenności, lecz także o długości trwania związków, o przeciętnym trwaniu życia ludzkiego i o rzeczy najistotniejszej, warunkującej rozwój każdego społeczeństwa - o dzietności rodzin. W tym obszarze ważne miejsce zajmują studia Marzeny Liedke, która po raz pierwszy w naszej historiografii na aż tak dużą skalę zbadała prokreację rodzin arystokratycznych Wielkiego Księstwa Litewskiego ${ }^{45}$. W badanych przez autorkę rodzinach magnackich średnia liczba dzieci dożywających wieku dorosłego (po oszacowaniu córek) wyniosła 2,3 dziecka na parę małżeńską, co zapewniało minimalną zastępowalność pokoleń w tej grupie społecznej. Ostatnio badaczka podjęła także ciekawą próbę określenia, na ile wyznanie mogło wpływać na liczbę dzieci w rodzinach magnackich różnych wyznań chrześcijańskich funkcjonujących na terenie przedrozbiorowej Rzeczypospolitej ${ }^{46}$. Z przeprowadzonych analiz wynika, że czynniki religijne i mentalne nie miały wpływu na postawy prokreacyjne magnaterii polskiej i litewskiej, ponieważ średnia liczba dzieci zarówno w stadłach prawosławnych, kalwinistów, jak i katolików znacząco się nie różniła. Nieco odmiennie, moim zdaniem, działo się w zróżnicowanych wyznaniowo rodzinach miejkkich, wśród których stadła protestantów charakteryzowały się nie tylko późniejszym ich zawieraniem, lecz także większą skłonnością do wcześniejszego kończenia prokreacji i kontroli pożycia małżeńskiego ${ }^{47}$. Równolegle ukazywały się prace Piotra Guzowskiego charakteryzujące dzietność par szlacheckich od późnego średniowiecza po schyłek okresu przedrozbiorowego, oparte przede wszystkim na danych genealogicznych i testamentach ${ }^{48}$. Całościowe podsumowanie wyników realizowanych przez niego analiz, skonfrontowanych dodatkowo z najnowszymi ustaleniami dotyczącymi szlacheckiej komórki rodzinnej w poszczególnych krajach Europy, zawarł w studium opublikowanym w 2019 r. ${ }^{49}$ Trzeba podkreślić znaczenie naukowe wyników dociekań tego autora, wcześniej bowiem rodzina tej skądinąd uprzywilejowanej grupy społecznej, sprawującej w kraju monopol polityczny, która ukształtowała specyficzny system gospodarczy, bardzo rzadko była obiektem zainteresowań studiów demograficznych, bazujących z reguły na źródłach narracyjnych i normach prawnych. W przeciętnej rodzinie szlacheckiej liczba dzieci dożywających wieku dorosłego w późnym średniowieczu wynosiła 3,2, w XVIII stuleciu - 3,4, a 4,4 dziecka, gdy uwzględni się tylko rodziny mające potomstwo.

45 M. Liedke, Z badań nad prokreacją magnaterii Wielkiego Księstwa Litewskiego w XVI-XVIII wieku, „Przeszłość Demograficzna Polski” 2010, t. XXIX, s. 7-27; eadem, Demografia rodziny magnackiej w Wielkim Księstwie Litewskim na tle elit zachodnioeuropejskich. Wybrane problemy, „Przeszłość Demograficzna Polski” 2015, t. XXX, nr 1, s. 37-70; eadem, Rodzina magnacka..., s. 119-128. M. Liedke, Zróżnicowanie wyznaniowe a postawy prokreacyjne magnaterii Rzeczypospolitej $w$ XVI i w pierwszej potowie XVII wieku, „Przeszłość Demograficzna Polski” 2017, t. XXXIX, s. 49-63.

47 C. Kuklo, Czy reformacja wptynęta na struktury demograficzne rodziny i jej funkcjonowanie w epoce staropolskiej, „Czasy Nowożytne” 2018, t. XXXI, s. 55-71.

48 Vide m.in.: P. Guzowski, Demografia rodziny szlacheckiej w świetle najnowszych badań genealogicznych, „Przeszłość Demograficzna Polski” 2011, t. XXX, s. 7-23.

49 P. Guzowski, Rodzina szlachecka w Polsce przedrozbiorowej. Studium demograficzne, Białystok 2019. 
Podjęto również badania nad postawami prokreacyjnymi mieszczanek (Piotr Łozowski, Jolanta Skierska ${ }^{50}$ i chłopek (Jacek Siebel) ${ }^{51}$, choć w tym wypadku ograniczone do wybranych miast i wsi. W tej grupie zwraca uwagę studium Konrada Kołodziejczyka poświęcone charakterystyce demograficznej rodzin w parafii Nowy Korczyn w drugiej połowie XVIII w. z właściwym zastosowaniem metody rekonstrukcji rodzin opracowanej przez Louisa Henry’ego i wzorową prezentacją wyników, umożliwiających stosowną komparatystykę $e^{52}$.

Chociaż w wielu opracowaniach za teologią katolicką wskazywano na prokreację jako główny cel małżeństwa, to niewiele dotąd pisano o uwarunkowaniach szans na przeżycie dziecka znajdującego się w tonie matki i w chwili porodu, a także samej położnicy w okresie połogowym. Jednym z wielu takich czynników była wiedza i praktyka odnosząca się do organów kobiecych i jej zdrowia u osób asystujących przy porodzie ${ }^{53}$. Sytuacja w pewnym stopniu poprawiła się za sprawą studiów Jakuba Węglorza, Weroniki Koceli, a ponadto Katarzyny Justyniarskiej-Chojak i Beaty Wojciechowskiej, charakteryzujących stan wiedzy medycznej w okresie staropolskim, w tym dotyczącej zdrowia i chorób kobiecych ${ }^{54}$. Należy zauważyć, że Weronika Kocela silniej podkreśliła w swej pracy różnorodność i wielopłaszczyznowość roli kobiety w kształtowaniu się kultury medycznej w naszym kraju w drugiej połowie XVIII w., a także nakreśliła wizerunek bab i akuszerek oraz samych położnic zawarty na kartach poradników medycznych. Z kolei książka Małgorzaty Stawiak-Ososińskiej szeroko i gruntownie, w skali całej Rzeczypospolitej, przybliżyła ważne zagadnienie kształcenia akuszerek w ostatnim ćwierćwieczu przed utratą niepodległości ${ }^{55}$. Przeżywanie przez kobiety

50 P. Łozowski, Demografia rodziny mieszczańskiej w Starej Warszawie w pierwszej potowie XV wieku, „Przeszłość Demograficzna Polski” 2014, t. XXXIV, s. 7-24; J. Skierska, Ludność Zielonej Góry w latach 1652-1766 w świetle ksiag metrykalnych, Zielona Góra 2015.

51 J. Siebel, Ludność parafii bogucickiej (województwo śląskie) w latach 1738-1860 (na podstawie ksiag metrykalnych), Katowice 2012.

52 K. Kołodziejczyk, Rodzina w parafii Nowy Korczyn w drugiej potowie XVIII wieku na podstawie ksiag metrykalnych (częśc 1), „Przeszłość Demograficzna Polski” 2016, t. XXX, s. 55-78; część 2, „Przeszłość Demograficzna Polski” 2017, t. XXXIX, s. 65-95.

53 Poza zakresem moich uwag pozostawiam cały zespół czynników warunkujących położenie bytowo-sanitarne społeczeństwa polskiego i tym samym prace nawiązujące do wspomnianego zagadnienia.

54 J. Węglorz, Staropolskie poradniki medyczne o zdrowiu i chorobach kobiet, [w:] Per mulierem..., s. 421-432; idem, Zdrowie, choroba i lecznictwo w spoteczeństwie Rzeczypospolitej XVI-XVIII wieku, Toruń 2015; W. Kocela, Trudna sztuka babienia. Kultura medyczna Polski w II potowie XVIII wieku, Warszawa 2020; K. Justyniarska-Chojak, Troska o zdrowie kobiet w polskich zielnikach z XVI wieku, [w:] Per mulierem..., s. 407-420; B. Wojciechowska, Porady dla kobiet cięzarnych i rodzacych w wybranych pracach od późnego antyku do wczesnej nowożytności, „Medycyna Nowożytna” 2014, t. XX, z. 1, s. 145-151.

55 M. Stawiak-Ososińska, Sztuka potożnicza dla kobiet. Ksztatcenie akuszerek na ziemiach polskich $w$ dobie niewoli narodowej (1773-1914), Warszawa 2019; vide recenzję B. Urbanek, „Medycyna Nowożytna” 2019, t. XXV, z. 1, s. 181-186. Vide także: H. Kurowska, Terminologia potożnicza w polskich drukowanych podręcznikach akuszerii i anatomii z II potowy XVIII wieku, „Medycyna Nowożytna” 2018, t. XXIV, z. 3 (suplement), s. 153-170. 
okresu noszenia dziecka pod sercem, a następnie połogu, charakteryzowała też Wiktoria Trzpiot $^{56}$. Sporo nowego do naszej wiedzy o dawnej medycynie zawiera również tom interdyscyplinarnych studiów odwołujących się do świadectw pisanych, ikonograficznych i archeologicznych, zredagowany przez Sylwię Konarską-Zimnicką, Lucynę Kostuch i Beatę Wojciechowską $a^{57}$.

Niewiele natomiast pisano o niepłodności, przy czym to głównie kobiety obwiniano za brak potomstwa. W tym kontekście trzeba zaakcentować interesujące szkice Doroty Żołądź-Strzelczyk, podnoszące zarówno osobisty, jak i społeczny wymiar bezdzietności, a w przypadku rodzin panujących nawet polityczny, oraz Urszuli Kicińskiej, przybliżający traktowanie kobiecej bezpłodności w wystąpieniach świeckich i zakonnych duchownych katolickich ${ }^{58}$. Musiało to zjawisko mieć znaczenie w codziennej egzystencji społeczeństwa staropolskiego, w którym brak potomstwa dotyczył około jednej czwartej szlacheckich i magnackich par małżeńskich w Koronie oraz aż jednej trzeciej związków magnatów litewskich.

Spore zainteresowanie badawcze budziła pozycja nie tylko żony i matki, lecz także wdowy w ramach rodziny, jako małej, zwartej grupy, w której wszyscy członkowie (włącznie z dziadkami, wnukami i krewnymi) mieli określone funkcje i pozostawali na co dzień w bliskich relacjach ${ }^{59}$. O więziach małżeńskich w środowisku chłopów pisał Tomasz Wiślicz ${ }^{60}$, w miastach i miasteczkach sprawę naświetliły Katarzyna Justyniarska-Chojak ${ }^{61}$ oraz Bernadetta Manys ${ }^{62}$, a w kręgach familii szlacheckich i magnackich - Jarosław Pietrzak ${ }^{63}$. Pisząc o relacjach rodzinnych, niektórzy autorzy, tacy jak Magdalena Kolarska, położyli szczególny nacisk na zobrazowanie miłości małżeńskiej oraz sposoby jej artykułowania. Miała ona bowiem, oprócz prokreacji, stanowić mocny fundament

56 W. Trzpiot, Stan btogostawiony czy „nieznośne męki”? Kobieta staropolska w okresie ciąży i potogu w świetle memuarów, [w:] Per mulierem..., s. 433-449.

57 Medicina antiqua, mediaevalis et moderna. Historia - filozofia - religia, red. S. Konarska-Zimnicka, L. Kostuch, B. Wojciechowska, Kielce 2019.

58 D. Żołądź-Strzelczyk, Osobisty i spoteczny wymiar bezdzietności w dawnej Polsce, [w:] Gospodarka, spoteczeństwo, kultura $w$ dziejach nowożytnych. Studia ofiarowane Pani Profesor Marii Boguckiej, red. A. Karpiński, E. Opaliński, T. Wiślicz, Warszawa 2010, s. 103-112; U. Kicińska, Problem ptodności i bezptodności w oracjach pogrzebowych XVII wieku poświęconych kobietom, [w:] W kręgu rodziny epok dawnych. Dziecinstwo, red. B. Popiołek, A. Chłosta-Sikorska, M. Gadocha, Warszawa 2014, s. 125-140. Vide tom prac: Conjux, mater, filia, soror propinqua, civis... Kobieta na ziemi wschowskiej i pograniczu wielkopolsko-śląskim, red. M. Małkus, K. Szymańska, Wschowa-Leszno 2016.

60 T. Wiślicz, Upodobanie...

${ }^{61}$ K. Justyniarska-Chojak, Najlepszemu i najściślejszemu przyjacielowi... - więzi matżeńskie w testamentach mieszczańskich z terenu Matopolski w XVI wieku, [w:] Kobieta i mężczyzna..., s. 73-82.

62 B. Manyś, Więzi emocjonalne między matżonkami w testamentach mieszkańców Wilna i jego okolic z lat 1733-1763, [w:] ibidem, s. 95-106.

63 J. Pietrzak, Korespondencja Katarzyny z Sobieskich ks. Radziwittowej (1634-1694) jako źródto do poznania jej relacji rodzinnych, [w:] Kobiece kregi korespondencyjne w XVII-XIX wieku, red. B. Popiołek, U. Kicińska, A. Słaby, Warszawa-Bellerive-sur-Allier 2016, s. 13-30. 
rodziny chrześcijańskiej ${ }^{64}$. Wartościowy przyczynek do dziejów żon i córek świeckich duchownych unickich w czasach saskich i stanisławowskich napisał Witold Bobryk ${ }^{65}$.

W nurcie historii kobiet, życia rodzinnego (rodzinności, której rolę i rangę wyznaczają więzi pokrewieństwa i powinowactwa), obyczajów i uczuć należy sytuować rozprawę Bernadetty Manyś o modelach obrzędów rodzinnych w osiemnastowiecznym Wilnie, zwłaszcza zaś prace Agnieszki Jakuboszczak o przeżywaniu życia rodzinnego przez szlachcianki w Wielkopolsce oraz Karoliny Stojek-Sawickiej o życiu codziennym kobiet w dworach szlacheckich ${ }^{66}$. O uczuciach rodzicielskich matek, o ich zaangażowaniu w donoszenie ciąży, ale też o obawach o pośmiertne losy duszy nieochrzczonego dziecka, będącymi obrazem postaw religijnych położnic, pisała Małgorzata Delimata-Proch ${ }^{67}$. Ciągle mało wiemy o kobiecych reakcjach i emocjach wyrażanych z powodu chorób najbliższych członków rodziny, w tym najmłodszych ${ }^{68}$, a także ich śmierci. Skromne wyobrażenie o tym daje obraz żeńskich postaw kulturowych dotyczących obyczajów funeralnych i form komemoracji zmarłych ${ }^{69}$.

Za osobny wątek można uznać prace zwracające uwagę na konflikty rodzinne z udziałem kobiet, o których pisali Marian Surdacki, Magdalena Wilczek-Karczewska, Dominika Burdzy, Dorota Żurek i Anna Penkała ${ }^{70}$. Jednymi z ciekawszych esejów w tej

64 M. Kolarska, Listy Elżbiety z Branickich i Jana Tarto jako przyktad korespondencji mitosnej w epoce saskiej, [w:] ibidem, s. 79-90.

65 W. Bobryk, Popadie i popówny - żony i córki kaptanów unickich w XVIII wieku, [w:] Per mulierem..., s. $205-210$.

66 B. Manyś, Uroczystości rodzinne w Wilnie za panowania Augusta III (1733-1763), Poznań 2014; A. Jakuboszczak, Rodzina i rodzinność szlachcianek wielkopolskich w XVIII wieku. Perspektywa kobieca, Poznań 2016; K. Stojek-Sawicka, Szlachcianki w świecie sarmackim. Jak żyty kobiety na dworach szlacheckich $w$ dawnej Polsce, Warszawa 2013.

${ }_{67}$ M. Delimata-Proch, Ciąża, poród oraz potóg w świetle polskich ksiag cudów i task (od średniowiecza do XVIII w.), „Kwartalnik Historii Kultury Materialnej” 2015, t. LXIII, nr 3, s. 433-449.

68 Uwagę zwraca analiza matczynej postawy Anny z Mycielskich Radziwiłłowej autorstwa B. Manyś, O problemach zdrowotnych magnackich dzieci w XVIII w. na przyktadzie potomstwa Michata Kazimierza Radziwitta zw. Rybeńko i Anny z Mycielskich Radziwittowej, „Medycyna Nowożytna” 2018, t. XXIV, z. 2, s. 85-102. Skromnie wypadają rozważania dotyczące okresu staropolskiego w tomie Mitość idealna, mitość dziecka, red. B. Płonka-Syroka, A. Szlagowska, A. Syroka, K. Marchel, Wrocław 2013.

69 W interesującym skądinąd tomie Nie wszystek umrę. Pamięć o zmartych w kulturze staropolskiej, red. A. Jankowska, A. Klonder, Bydgoszcz 2015, wśród 22 tekstów jedynie dwa odnoszą się do przechowywania pamięci o zmarłych kobietach: U. Kicińska, Oracja pogrzebowa jako upamiętnienie zmartego (s. 189-199) i W. Duży, Wspomnienia o zmartych rodzicach w wybranych zapiskach pamiętnikarskich zprzetomu XVIII i XIX wieku (s. 271-281).

70 M. Surdacki, Rodzina i jej problemy w Urzędowie w czasach staropolskich, [w:] Spoteczeństwo staropolskie..., s. 227-244; M. Wilczek-Karczewska, Konflikty rodzinne na tle majątkowym w świetle wielkopolskich inwentarzy i testamentów z XVII wieku. Zarys problematyki, [w:] ibidem, s. 149-169; D. Burdzy, Perypetie matżeńskie mieszczan sandomierskich w XVI wieku, [w:] Kobieta i mężczyzna..., s. 37-46; D. Żurek, Matżeństwa mieszczan Chrzanowa do potowy XVII wieku, [w:] ibidem, s. 47-55; A. Penkała, "Od postanowienia wspólnego ustawiczne przeklęctwa, stów nieuczciwych wotania, hatasy”. (Nie)codzienność szlacheckiego domu w świetle zapisów z osiemnastowiecznych ksiag grodzkich z terenu województwa krakowskiego, [w:] Ceremonie i tradycje rodzinne..., s. 93-103. 
grupie są szkice Bożeny Popiołek traktujące o kwestiach przemocy zarówno kobiecej, jak i wobec kobiet ${ }^{71}$, oraz Małgorzaty E. Kowalczyk o pożyciu małżeńskim z kobietą cierpiącą na zaburzenia psychiczne ${ }^{72}$. Warto dodać, że osobne studium poświęcone licznym przykładom mniej chwalebnej stronie pożycia w rodzinach i małżeństwach szlachty krakowskiej, rozpatrywanym przez sąd grodzki w czasach saskich, opublikowała Anna Penkała ${ }^{73}$. Zauważono też negatywny wpływ nadużywania alkoholu na organizm kobiecy ${ }^{74}$.

2. W drugiej grupie omawianych w tej części artykułu monografii znalazły się prace uwzględniające okres dzieciństwa dziewczynek, ich wychowanie i edukację, a także zabawy i zabawki. Tego rodzaju zainteresowanie naukowe znalazły ostatnio wyraz przede wszystkim w pracach Doroty Żołądź-Strzelczyk i Katarzyny Kabacińskiej-Łuczak ${ }^{75}$. Generalnie można nawet zaryzykować stwierdzenie o pewnej intensyfikacji zainteresowań tego rodzaju, zważywszy na ukazanie się całkiem niedawno dwóch tomów, w których tytule pomieszczono wymiar świata dziecięcego. Pierwszy z nich, zatytułowany Dziecinstwo, otwiera serię $W$ kregu rodziny epok dawnych, a został przygotowany przez Bożenę Popiołek i jej współpracowników: Agnieszkę Chłostę-Sikorską i Marcina Gadochę $^{76}$. Zawiera on aż 41 większych i mniejszych objętościowo tekstów (w tym ponad połowa dotyczy XVI-XVIII w.) charakteryzujących przestrzeń dziecka w obrębie najmniejszej grupy społecznej nie tylko na ziemiach polskich, lecz także w Anglii, Czechach, Niemczech, Turcji, Wielkiej Brytanii, kolonialnej Wirginii i na Litwie. Można się tylko cieszyć z ambicji grona autorskiego, pragnącego uchwycić dzieciństwo w kontekście uwarunkowań historycznych, antropologicznych i kulturowych. Jednak biorąc pod uwagę cel mojego przeglądu badań, trzeba krytycznie przyznać, że bohaterami większości wypowiedzi byli zazwyczaj synowie oraz dzieci i młodzież, tylko sporadycznie zaś córki, co oczywiście po trosze wynika z niedostatków źródłoznawczych ${ }^{77}$.

71 B. Popiołek, Męska zbrodnia, kobiecy ból. Drobna przemoc w czasach saskich, [w:] Kobieta i mężczyzna..., s. 83-93.

72 M.E. Kowalczyk, Żona moja, która mnie zawsze najlepiej kochata, [...] dusza cata okazuje się mnie nienawidzić, czyli problemy matżenskie Agnieszki i Stanistawa Treterów, [w:] ibidem, s. 369-377.

73 A. Penkała, Przeciw prawu, tradycji i obyczajowi. Sprawy procesowe szlacheckich matżenstw w ksiegach sąów grodzkich z terenu województwa krakowskiego w czasach saskich, Kraków 2017.

74 J. Pietrzak, W szponach natogu. Alkoholizm kobiet w epoce staropolskiej na przyktadzie Joanny z Denhoffów Denhoffowej (zm. 1720), [w:] Antropologia używek w gospodarce i życiu spotecznym, red. J. Żychlińska, A. Głowacka-Penczyńska, J. Woźny, Bydgoszcz 2016, s. 57-75.

75 D. Żołądź-Strzelczyk, K. Kabacińska-Łuczak, Codzienność dziecięca opisana stowem i obrazem. Życie dziecka na ziemiach polskich od XVI do XVIII wieku, Warszawa 2012; D. Żołądź-Strzelczyk, A cacek też dużo byto. Zabawki dziecięce na ziemiach polskich w średniowieczu i epoce nowożytnej, „Kwartalnik Historyczny" 2013, t. CXX, nr 1, s. 5-30, zwłaszcza s. 23 i n.; eadem, Rola zabawek w przygotowaniu do petnienia funkcji spotecznych kobiecych i męskich w epoce nowożytnej, [w:] Kobieta i mężczyzna..., s. 469-482.

76 Wregu rodziny epok dawnych...

77 Dzieciństwo córek dostrzegli w swoich tekstach Dorota Żołądź-Strzelczyk, Jerzy Urwanowicz, Agnieszka Słaby, Anna Szylar, Iwona Kulesza-Woroniecka. 
Drugi zbiór studiów zawierający ustalenia historiografii na temat dzieciństwa i starości został przygotowany przez dwie historyczki z Lublina: Annę Obarę-Pawłowską i Małgorzatę Kołacz-Chmiel ${ }^{78}$. Chociaż większość z 17 prac dotyczy czasów średniowiecznych, to zwracają uwagę artykuły Doroty Żołądź-Strzelczyk i Katarzyny Justyniarskiej-Chojak ${ }^{79}$. Pierwszy z nich charakteryzuje cenny materiał do badań nad przeszłością dziecka na ziemiach polskich oraz proponuje problematykę możliwą do odtworzenia w ich świetle, drugi zaś omawia regulacje prawne dotyczące dzieci w miastach i miasteczkach staropolskich oraz praktykę dnia codziennego w tym zakresie.

Osobno, choć w powiązaniu z wczesnym etapem życia dziecka, rozwijały się badania nad wychowaniem i edukacją dziewczynek. Model wychowania dziewcząt w Polsce w czasach renesansu przedstawiła Jaśmina Korczak-Siedlecka ${ }^{80}$. Jednakże najwięcej jak do tej pory pisano o działalności pensji dla dziewcząt świeckich w klasztorach żeńskich. Cenne są tutaj zwłaszcza studia Anny Szylar ${ }^{81}$. Nieco mniej wiemy o dworach magnackich, będących również środowiskiem wychowawczym (m.in. Feliksa Czackiego, podczaszego wielkiego koronnego ${ }^{82}$, i najmniej o edukacji domowej. Z pracy Stanisława Litaka poświęconej szkołom parafialnym w okresie potrydenckim wynika, że dziewczęta rzadko uczyły się w takich placówkach, choć częściej można je było spotkać w regionach pozostających pod wpływem kultury niemieckiej. Autor przytoczył m.in. przykład Prus Królewskich, na terenie których nauczanie dziewcząt wspólnie z chłopcami lub oddzielnie w XVII w. miało być regułą 83 . Także Roman Pelczar poświęcił szkic edukacji dziewcząt $\mathrm{w}$ szkołach elementarnych w lacińskiej diecezji przemyskiej w czasach porozbiorowych ${ }^{84}$. Parafialne spisy ludności przeprowadzone na początku lat dziewięćdziesiątych XVIII stulecia na polecenie Komisji Porządkowych Cywilno-Wojskowych, najpełniej zachowane dla województwa krakowskiego i Kujaw, poświadczają niekiedy

\section{Dziecinstwo i starość...}

79 D. Żołądź-Strzelczyk, Dzieciństwo w epoce staropolskiej - możliwości źródtowe i kierunki badań, [w:] ibidem, s. 227-242; K. Justyniarska-Chojak, Dziecko w rodzinie mieszczańskiej w XVI-XVIII wieku wświetle przepisów prawa magdeburskiego (pomiędzy norma a praktyka), [w:] ibidem, s. 243-266.

80 J. Korczak-Siedlecka, Model wychowania dziewczat w szesnastowiecznej Polsce, „Odrodzenie i Reformacja w Polsce" 2013, t. LVIII, s. 49-71.

81 A. Szylar, Dziatalność wychowawczo-edukacyjna żeńskich zgromadzeń zakonnych w Matopolsce w okresie potrydenckim do 1815 roku, Kraków 2012; eadem, Ideaty wychowawcze w klasztornych szkotach żeńskich w okresie potrydenckim do początków XIX wieku, „Paedagogia Christiana” 2012, nr XXX(II), s. 11-27; eadem, Naprzód zaraz wstana, kiedy ich obudza..., czyli panny świeckie na edukacji u wizytek warszawskich, [w:] Per mulierem..., s. 211-230; eadem, „Zostawili córki trzy na edukację u nas..., czyli o klasztornym wychowaniu dziewczat $w$ XVIII i na poczatku XIX wieku, [w:] W kregu rodziny epok dawnych..., s. 323-338.

82 Cf. D. Żołądź-Strzelczyk, „Pod każdym względem szlachetne ci daje wychowanie...”. Studia z dziejów wychowania szlachty w epoce staropolskiej, Wrocław 2017, s. 171-184. Także o wychowaniu córek Jana Potworowskiego, reprezentanta braci czeskich w Wielkopolsce, wysłanych z bratem do Berlina: ibidem, s. 139-156.

83 S. Litak, Edukacja poczatkowa w polskich szkotach w XIII-XVIII wieku, Lublin 2010, s. 193.

84 R. Pelczar, Szkoty trywialne dla dziewcząt w tacińskiej diecezji przemyskiej w czasach zaborów, „Przegląd Historyczno-Oświatowy” 2014, t. LVII, nr 1-2, s. 20-41. 
obecność dziewczynek, częściej z rodzin mieszczańskich niż chłopskich, uczęszczających do szkół parafialnych. Dorota Żołądź-Strzelczyk przypomniała treść pierwszego rodzimego podręcznika nauczania podstawowego dla dziewcząt, opracowanego przez Antoniego Maksymiliana Prokopowicza w 1790 r. i dedykowanego krakowskim prezentkom, które zajmowały się ich nauczaniem ${ }^{85}$.

Trwają nadal, chociaż nie tak intensywne, badania nad gospodarczą działalnością staropolskich kobiet, i to we wszystkich grupach społecznych. Ich aktywność na tym polu w środowisku mieszczańskim od lat charakteryzuje Andrzej Karpiński ${ }^{86}$, a ostatnio także Dominika Burdzy ${ }^{87}$. Warto zauważyć wydobyty przez Cezarego Kardasza dla miast południowego pobrzeża Bałtyku i przez Piotra Łozowskiego dla Starej i Nowej Warszawy niemały, bo sięgający około $15 \%$ udział kobiet w transakcjach kredytowych ${ }^{88}$. Pisząc o pracy wieśniaczek, na ogół podkreślano ich wysiłki oraz starania w obrębie gospodarstwa domowego i rolniczego, pracy niemającej końca, rzadko dostrzegając może oprócz pracy najemnej w charakterze dziewek służebnych - inne potencjalne obszary działań kobiecych. Ważne, aby w tym miejscu odnotować cenną charakterystykę aktywności wieśniaczek małopolskich w późnym średniowieczu w życiu ekonomicznym wsi i jej najbliższego sąsiedztwa poczynioną przez Małgorzatę Kołacz-Chmiel ${ }^{89}$. Były one widoczne zwłaszcza na rynku sprzedaży nieruchomości, a ponadto na lokalnym rynku kredytowym, i to przede wszystkim w charakterze udzielających pożyczek. $\mathrm{O}$ jednej z bardziej przedsiębiorczych ekonomicznie i społecznie wiejskich kobiet, niejakiej Agnieszce sołtysowej ze wsi Krościenko Wyżne, pisał Piotr Guzowski ${ }^{90}$.

85 D. Żołądź-Strzelczyk, Antoniego Maksymiliana Prokopowicza "Sposób nowy najtatwiejszy pisania i czytania razem dla panienek z przypisami dla nauczycielek" - pierwszy polski podręcznik edukacji elementarnej dla dziewczat, „Kwartalnik Historii Kultury Materialnej” 2014, t. LXII, nr 4, s. 553-565.

86 A. Karpiński, Przekupki wileńskie w drugiej potowie XVII i w początkach XVIII wieku, [w:] Per mulierem..., s. 369-393.

87 D. Burdzy, Aktywność gospodarcza i kulturalna kobiet w Sandomierzu w XVI wieku, [w:] ibidem, s. 249-259.

88 C. Kardasz, Rynek kredytu pieniężnego w miastach potudniowego pobrzeża w późnym średniowieczu (Greifswald, Gdańsk, Elblag, Toruń, Rewel), Toruń 2013; P. Łozowski, Kredyt i dom. Rynki obrotu pieniężnego i nieruchomości w Warszawie okresu XV i początków XVI wieku, Białystok 2020. Vide: idem, Stan badań nad kobietami w miastach późnośredniowiecznych na ziemiach polskich, „Przeszłość Demograficzna Polski” 2015, t. XXXVII, nr 1, s. 71-91. Cf. A. Girsztowt, Kobiety na elblaskim rynku renty w okresie średniowiecznym, „Komunikaty Mazursko-Warmińskie” 2013, nr 281, s. 481-498.

89 M. Kołacz-Chmiel, Mulier honesta et labioriosa. Kobieta w rodzinie chtopskiej późnośredniowiecznej Matopolski, Lublin 2018, s. 271-315. Vide: eadem, Kobieta w rodzinie i spoteczności chtopskiej na pograniczu polsko-ruskim. Stan i perspektywy badań, [w:] Region i regionalizm $w$ archeologii i historii, red. J. Hoff, S. Kadrow, Rzeszów 2013.

90 P. Guzowski, Agnieszka - sottysowa z Krościenka Wyżnego, [w:] Granice i pogranicza. Mikrohistorie $i$ historie życia codziennego, red. P. Guzowski, M. Liedke, M. Ocytko, Kraków 2011, s. 39-54. Jeszcze inny przykład mikrohistorii losu kobiecego, tym razem bardzo młodej, bo zaledwie 12-letniej dziewczyny wiejskiej ukazał M. Wyżga, Zty los Matgosi Madejszczonki? Mikrohistoria spod osiemnastowiecznego Ojcowa, [w:] Kobieta i mężczyzna..., s. 307-315. 
Mniejszą uwagę badaczy przyciągała grupa najemnych pracowniczek fizycznych w środowisku wiejskim i miejskim, chociaż w tym drugim, na przykładzie Krakowa, Poznania i Warszawy, doczekały się one opracowania autorstwa Radosława Poniata ${ }^{91}$. Za sprawą Katarzyny Pękackiej-Falkowskiej i Bartosza Drzewieckiego pojawiły się też informacje o próbach zreformowania środowiska zawodowych akuszerek, przynajmniej w niektórych wielkich miastach pruskich ${ }^{92}$. Temu też środowisku osobną rozprawkę poświęciła Hanna Kurowska ${ }^{93}$.

Oprócz samego położenia prawnego kobiet w okresie staropolskim i ich występowania przed sądami w sprawach majątkowych zwrócono wreszcie uwagę na ich działalność przestępczą, począwszy od kradzieży lub grabieży, przez występki przeciw moralności, a na zabójstwie, najczęściej własnego niemowlęcia lub męża, skończywszy. O przestępstwach kryminalnych popełnionych przez kobiety w środowisku wiejskim wspominał Tomasz Wiślicz"94; o miejskim pisali Aneta Głowacka-Penczyńska, Joanna Kościelna, Łukasz Truściński i Andrzej Karpiński ${ }^{95}$, natomiast wśród elity szlacheckiej - Agnieszka Jakuboszczak i Jarosław Pietrzak ${ }^{96}$. Z badań Marcina Kamlera wynika, że w krwawych porachunkach szlachty szadkowskiej i sieradzkiej w XVII stuleciu wystąpiło ponad 420 szlachcianek, których większość co prawda była ofiarami przemocy, lecz kilkadziesiąt z nich swoją agresją dorównywało przemocy mężczyzn (najeżdżały wrogów, raniły i zabijały) ${ }^{97}$. W opinii Kamlera jedną z ważniejszych przyczyn sąsiedzkich i rodzinnych kłótni były roszczenia majątkowe, w tym próby odzyskiwania posagów i wian od wdów oraz podziały majątków między spadkobiercami ${ }^{98}$.

91 R. Poniat, Stużba domowa w miastach na ziemiach polskich od potowy XVIII do końca XIX wieku, Warszawa 2014; vide recenzję A. Karpińskiego, „Przegląd Historyczny” 2015, t. CVI, z. 2, s. 395-402.

92 K. Pękacka-Falkowska, Dyscyplinować i pomagać - toruńskie akuszerki miejskie w XVIII w. (kilka uwag na marginesie przysiag i porządków akuszerskich), „Medycyna Nowożytna” 2013, t. XIX, z. 2, s. 65-105; K. Pękacka-Falkowska, B. Drzewiecki, Projekt porzadku akuszerskiego Towarzystwa Przyrodniczego $w$ Gdan'sku (Naturforschende Gesellschaft) z 1781 r., „Medycyna Nowożytna” 2019, t. XXV, z. 2, s. 47-66.

$93 \mathrm{H}$. Kurowska, Akuszerka na ziemiach polskich w świetle przepisów i literatury medycznej z końca XVIII i pierwszej potowy XIX wieku, „Studia Zachodnie” 2015, t. XVII, s. 219-238.

94 T. Wiślicz, Upodobanie...

95 A. Głowacka-Penczyńska, Spotkanie z katem. Mieszkanki matych miast Wielkopolski i Kujaw przed sądem w drugiej potowie XVI i w XVII wieku, [w:] Per mulierem..., s. 299-309; J. Kościelna, Dzieciobójstwo i zabójstwo dziecka w Chojnie (Königsberg in der Neumark) od końca XVI do początków XVIII w., „Nadwarciański Rocznik Historyczno-Archiwistyczny” 2014, t. XXI, s. 87-121; Ł. Truściński, Kobieta w obliczu sądu w późnośredniowiecznym Krakowie - sprawy karne, [w:] Per mulierem..., s. 287-297; A. Karpiński, Więźniowie poznańskiego ratusza w latach 1790-1793, „Przegląd Historyczny" 2014, t. CV, z. 3, s. 379-398.

96 A. Jakuboszczak, Kobieta morderczyni. Sprawa o mężobójstwo na przyktadzie osiemnastowiecznego procesu Konstancji Dobrowolskiej, [w:] Per mulierem..., s. 311-317; J. Pietrzak, Zbrodnia to niestychana, Pani zabita Pana. Sprawa Marianny z ks. Sapiehów Dąmbskiej o matzonkobójstwo - studium przypadku, [w:] Conjux, mater, filia..., s. 249-281.

97 M. Kamler, Przemoc między szlachta sieradzka w XVII wieku. Opis zjawiska, Warszawa 2011; vide recenzję A. Karpińskiego, „Kwartalnik Historyczny” 2012, t. CXIX, nr 3, s. 614-620.

98 M. Kamler, Przemoc między szlachta w Polsce w XVII w. - zjawisko masowe?, „Kwartalnik Historyczny” 2014, t. LXXI, nr 3, s. 541-569. 
Osobno należałoby wskazać nieliczne prace poświęcone marginesowi społecznemu, przede wszystkim szkic Przemysława Jędrzejewskiego ${ }^{99}$, a także tom Moniki Maludzińskiej, w którym zajęto się najuboższą zbiorowością mieszkańców oświeceniowej Warszawy, gdzie kobiety stanowity znaczącą część ${ }^{100}$. Podobnie skromny charakter mają najnowsze osiągnięcia badawcze nad prześladowaniem czarownic, choć podzielam opinię Jacka Wijaczki, znawcy zagadnienia, że jednym z powodów, oprócz rozproszenia materiału źródłowego, jest niedocenianie „dostatecznie wpływu wiary w czarownice i diabła na codzienne życie we wczesnonowożytnej Rzeczypospolitej”101. Wśród najnowszych prac tego badacza uwagę zwraca zwłaszcza książka charakteryzująca, po raz pierwszy na taką skalę w naszej historiografii, stosunek polskiego Kościoła rzymskokatolickiego do sądzenia osób oskarżonych o przestępstwo czarostwa w przedrozbiorowej Polsce ${ }^{102}$, a także artykuł poświęcony procesom czarownic w stolicy luterańskich Prus Królewskich ${ }^{103}$. W Gdańsku w XVI-XVII w. przeprowadzono 25 takich procesów, w których oskarżono 33 kobiety ( 17 z nich stracono, a tylko cztery uniewinniono) i zaledwie trzech mężczyzn. Charakterystyczne, że wszystkie one wywodziły się z najuboższych warstw miejskich lub ze wsi.

3. W ciągu ostatnich kilkunastu lat o wiele bardziej modne stały się badania nad udziałem kobiet $\mathrm{w}$ życiu politycznym i publicznym ${ }^{104}$ (trzecia grupa omawianych prac), szczególnie nad dworami magnatek, a także ich szeroko ujmowanym patronatem. Kobiecą aktywność w przywołanej przestrzeni życia społecznego w czasach pierwszych Wazów ukazał Edward Opaliński, za panowania Sasów Katarzyna Kuras i Bożena Popiołek, w drugiej połowie XVIII stulecia Jarosław Pietrzak, a w całym XVIII w. Agnieszka Jakuboszczak ${ }^{105}$. Ciekawe są konstatacje krakowskiej historyczki Bożeny

99 P. Jędrzejewski, Wyklęci przez spoteczeństwo. Codzienność ludzi marginesu krakowskiego zespotu miejskiego w 2. potowie XVIII wieku, [w:] Ceremonie i tradycje rodzinne..., s. 151-164.

100 M. Maludzińska, Próżnowanie stato się powszechnym natogiem. Żebracy i wtóczędzy w stanistawowskiej Warszawie, Warszawa 2014. Vide recenzje: R. Poniata, „Przegląd Historyczny” 2016, t. CVII, z. 2, s. 311-327; T. Srogosza, „Kwartalnik Historyczny” 2016, t. CXXII, nr 2, s. 378-382; oraz M. Rodaka, „Roczniki Dziejów Społecznych i Gospodarczych” 2016, t. LXXVI, s. 505-508.

101 J. Wijaczka, Procesy o czary w Prusach Ksiażecych (Brandenburskich) w XVI-XVIII wieku, wyd. 2 zmienione, Olsztyn 2019, s. 12.

102 Idem, Kościót wobec czarostwa w Rzeczypospolitej w XVI-XVIII wieku (na tle europejskim), Warszawa 2016.

103 Idem, Procesy o czary w Gdańsku w XVI-XVII wieku, „Przegląd Historyczny” 2019, t. CX, z. 3, s. 399-417; idem, Dzieci w procesach o czary. Casus Prus Ksiażęcych w XVII wieku, „Zapiski Historyczne" 2014, t. LXXIX, z. 1, s. 101-116; idem, Próba zimnej wody (ptawienie) w oskarżeniach i procesach o czary w państwie polsko-litewskim w XVI-XVIII wieku, „Odrodzenie i Reformacja w Polsce” 2016, t. LX, s. 73-110.

104 Vide np. zbiór 25 studiów od starożytności po wczesną nowożytność: Kobieta i wtadza w czasach dawnych, red. B. Czwojdrak, A.A. Kluczek, Katowice 2015. Skromnie wypada udział kobiet w okresie renesansu i baroku w tomie Kobieta niepoznana na przestrzeni dziejów, red. A. Obara-Pawłowska, A. Miączewska, D. Wróbel, Lublin 2017.

105 E. Opaliński, Aktywność kobiet w życiu publicznym w czasach pierwszych Wazów, [w:] Per mulierem..., s. 233-248; J. Pietrzak, Cate brzemię promocyi. O kobietach z rodzin królewskich $i$ magnackich jako o promotorkach awansów urzędniczych w Rzeczypospolitej drugiej potowy XVII wieku, [w:] Na przekór 
Popiołek, która podkreślając imponującą działalność rozpolitykowanej grupy niewiast w czasach późnosaskich, zauważyła, że była to mała grupka, której aktywność spotykała się z wyraźną krytyką męskiej części społeczeństwa szlacheckiego.

Wprawdzie nowych biografii nie doczekały się królowe z epoki renesansu, Bona i Anna Jagiellonka ${ }^{106}$, lecz osobnego, zbiorowego dzieła dorobiła się Maria Kazimiera d’Arquien, słynna Marysieńka, żona króla Jana III Sobieskiego ${ }^{107}$. Sama książka jest tym ciekawsza, że barwne życie i szeroko zakrojona działalność żony królewskiej na różnych polach nie wyszły spod pióra jednego autora, co zawsze grozi pewnym uproszczeniem charakterystyki postaci, lecz zostały napisane przez kompetentne grono autorskie. Z biografii magnatek otrzymaliśmy studium Pawła Tyszki o żonie pierwszego ordynata zamojskiego, Barbarze z Tarnowskich Zamoyskiej, pozostającej przez wiele lat na uboczu wielkiej polityki, do której powróciła dopiero po śmierci męża, a także Jarosława Pietrzaka o Katarzynie z Sobieskich Radziwiłłowej, podkanclerzynie i hetmanowej polnej litewskiej ${ }^{108}$. Książka Tyszki, oparta na niewielkim zasobie około 200 listów, generalnie sytuuje się w kręgu prac poświęconych kobiecym kręgom klientalno-korespondencyjnym. Ponadto zbiorowy portret niewiast $\mathrm{z}$ familii Zborowskich nakreśliła ostatnio Ewa Dubas-Urwanowicz ${ }^{109}$.

Ukazały się też studia charakteryzujące nie tylko funkcjonowanie, skład i organizację dworu królowej oraz arystokratek, lecz także - w jeszcze większym stopniu ich aktywność kulturową. Można tu przywołać chociażby pracę Katarzyny Kuras o dworze królowej Marii Leszczyńskiej oraz Agnieszki Słaby o dworze Elżbiety z Lubomirskich Sieniawskiej ${ }^{110}$. Życie i działalność ostatniej z nich na wielu polach

konwencjom. Nieszablonowe role spoteczne kobiet i mężczyzn od czasów nowożytnych do 1945 roku, red. M. Gibiec, D. Wiśniewska, L. Ziątkowski, Kraków 2019; K. Kuras, Rola wybitnych kobiet w polityce w czasach panowania Augusta III Sasa, [w:] Per mulierem..., s. 261-277; B. Popiołek, Między przestrzenia domowa a wielka polityką. Aktywność publiczna kobiet w czasach saskich, [w:] Drogi kobiet do polityki (na przestrzeni XVIII-XXI wieku), red. T. Kulak, M. Dajnowicz, Wrocław 2016, s. 27-44; A. Jakuboszczak, Aktywność polityczna wielkopolskich szlachcianek w XVIII wieku, [w:] ibidem, s. 45-58.

106 Z nielicznych opracowań warto zasygnalizować artykuł P. Szpaczyńskiego, Anna Jagiellonka kontra Jan Zamoyski. Kilka uwag w sprawie dążeń królowej do zapewnienia ciagtości dynastii Jagiellonów, „Klio” 2014, t. XXVIII, nr 1, s. 3-29. Natomiast popularny charakter ma książka K. Janickiego, Damy ztotego wieku, Kraków 2014.

107 A. Czarniecka, Królowa wdowa w polityce, [w:] Maria Kazimiera Sobieska (1641-1716). W kreggu rodziny, polityki i kultury, red. A. Kalinowski, P. Tyszka, Warszawa 2017, s. 149-165. Vide też: A. Markuszewska, Festa i muzyka na dworze Marii Kazimiery Sobieskiej w Rzymie (1699-1714), Warszawa 2012.

108 P. Tyszka, $W$ cieniu wielkiego kanclerza. Barbara $z$ Tarnowskich Zamoyska, Warszawa 2015; vide obszerną recenzję A. Słaby, „Czasy Nowożytne” 2017, t. XXX, s. 205-214. Cf. J. Pietrzak, Księżna dobrodziejka. Katarzyna z Sobieskich Radziwittowa (1634-1694), Warszawa 2016.

109 E. Dubas-Urwanowicz, Panie Zborowskie w XVI wieku, [w:] Z historii kultury staropolskiej. Studia ofiarowane Urszuli Augustyniak, red. A. Bartoszewicz, A. Karpiński, M. Ptaszyński, A. Zakrzewski, Warszawa 2020, s. 323-331.

110 K. Kuras, Dwór królowej Marii Leszczyńskiej. Ludzie, pieniądze, wptywy, Kraków 2018; A. Słaby, Rzadzicha oleszycka. Dwór Elżbiety z Lubomirskich Sieniawskiej jako przyktad patronatu kobiecego w czasach saskich, Kraków 2014; vide recenzję J. Dygdały, „Czasy Nowożytne” 2015, t. XXVIII, s. 238-242. 
aktywności społecznej cieszy się zresztą ostatnio dużym zainteresowaniem badawczym, czego dobrym przykładem może być opublikowany niedawno zbiorowy tom pod redakcją Bożeny Popiołek ${ }^{111}$.

Dopiero od niedawna zaczęto zwracać większą uwagę na klientelizm kobiecy, który w rodzimych badaniach był $\mathrm{z}$ reguły ograniczony do świata mężczyzn ${ }^{112}$. Tymczasem to, co wiemy z dotychczasowych badań nad środowiskami dworskimi, każe przypuszczać, że również magnacki dwór kobiecy, konstruowany przecież na podobieństwo mężowskiego, funkcjonował w procesie nieformalnej wymiany usług i korzyści. W tym kontekście należy wyróżnić najnowsze obszerne studium Bożeny Popiołek, która dogłębnie scharakteryzowała „zagadnienie patronatu kobiecego i budowania przez kobiety własnego zaplecza klientalnego" w pierwszej połowie XVIII w. ${ }^{113}$ Książka, oparta na rozległej, a przy tym różnorodnej podstawie źródłowej, co ma niebagatelne znaczenie, definiuje formy patronatu kobiecego oraz analizuje kobiece kręgi klientalne, jednak najwięcej uwagi poświęca aktywności na tym polu siedmiu zamożnych kobiet (Anna Franciszka z Gnińskich Zamoyska, Teresa z Potockich Zamoyska, Konstancja ze Słuszków Denhoffowa, Elżbieta z Lubomirskich Sieniawska, Konstancja Marianna z Potockich Szczukowa, Konstancja Ludwika z Tarłów Mniszchowa, Anna Katarzyna z Sanguszków Radziwiłłowa) i charakteryzuje ich dwory (strukturę, podstawy ekonomiczne, relacje międzyludzkie) w systemie więzi klientalnych ${ }^{114}$. Wiemy też więcej o różnych formach kobiecego patronatu religijnego (z dobroczynnością włącznie) i oświatowego ${ }^{115}$ oraz mecenatu artystycznego, w tym muzycznego ${ }^{116}$.

Niejednokrotnie nowe oblicze ponad 20 kobiet, zarówno tych bardziej znanych (Konstancja Marianna z Potockich Szczukowa, podkanclerzyna litewska, Elżbieta Sapieżyna, Anna Paulina z Sapiehów Jabłonowska), jak i tych mniej (Urszula z Morsztynów Dembińska, Agnieszka Truskolaska), znalazło odzwierciedlenie w specjalnym tomie dedykowanym kobietom słynnym czy to $\mathrm{z}$ racji urodzenia

111 Dziatalność Elżbiety z Lubomirskich Sieniawskiej. Polityka - gospodarka - kultura, red. B. Popiołek, Warszawa 2020.

112 U. Kicińska, Relacje patron-stuga w świetle korespondencji ekonomicznej Elżbiety z Lubomirskich Sieniawskiej, kasztelanowej krakowskiej, [w:] Tożsamość kobiet w Polsce: interpretacje, t. I (Od czasów najdawniejszych do XIX wieku), red. I. Maciejewska, Olsztyn 2016, s. 61-74.

113 B. Popiołek, Dobrodziejki i klienci. Specyfika patronatu kobiecego i relacji klientalnych w czasach saskich, Warszawa 2020, s. 21 (tam wyczerpujące przedstawienie stanu badań i literatury przedmiotu, z zagraniczną włącznie).

114 W najbliższych paru latach można oczekiwać wyników prac zespołu badawczego kierowanego przez Bożenę Popiołek, a pracującego nad zagadnieniem funkcjonowania szlacheckich dworów kobiecych.

115 O zaangażowaniu na tym polu zamożnych szlachcianek inflanckich wspomniał Ł. Wróbel, Dziatalność fundacyjna i oświatowa szlachty inflanckiej $w$ XVIII wieku na przyktadzie rodzin Borchów, Platerów i Hylzenów, [w:] Studia z dziejów edukacji w Rzeczypospolitej Obojga Narodów Korony i Litwy, red. K. Puchowski, J. Orzeł, Warszawa 2019, s. 123-139.

116 A.Ziontek, Siedlecki dwór artystyczny Aleksandry Ogińskiej, [w:] Mate miasta. Spoteczność, red. M. Zemło, Lublin 2011, s. 247-270; A. Markuszewska, Kompozytorki i patronki muzyki w XVII i XVIII wieku. Wybrane portrety, Warszawa 2017. Vide też: A. Jankowski, Patronka cywilizacyjnej przemiany. Biata legenda Marianny Skórzewskiej (1741-1773) wykreowana w dobie upadku Rzeczypospolitej, „Kwartalnik Historii Kultury Materialnej” 2014, t. LXII, nr 2, s. 227-241. 
i zamążpójścia, czy też z działalności literackiej i kolekcjonerskiej oraz z polityki i finansów w Koronie i na Litwie w XVIII stuleciu ${ }^{117}$.

W dotychczasowym obrazie staropolskich peregrynacji zagranicznych, począwszy od ich motywów i organizacji, a na charakterystyce spotykanych ludzi i odwiedzanych miejsc skończywszy, dominował obraz widziany oczami mężczyzn. Dopiero wydanie kilku kobiecych diariuszy z wojaży po Starym Kontynencie przez Bogdana Roka i Małgorzatę E. Kowalczyk zwróciło uwagę na zainteresowanie kobiet odbywaniem podróży i wytworzone przez nie z tej okazji piśmiennictwo ${ }^{118}$. Wspomniana dwójka badaczy wniosła duży wkład w poznanie zarówno samych kobiecych wędrówek, jak i ich przeżyć w zetknięciu się z nową, nieznaną rzeczywistością ${ }^{119}$. Natomiast Małgorzata E. Kowalczyk jest autorką pierwszego w naszym kraju większego opracowania, które przedstawia zagraniczne podróże Polek w epoce oświecenia, odbywane głównie przez reprezentantki zamożnej elity szlacheckiej. Wartość pracy tej historyczki podnosi nie tylko ukazanie powodów podejmowania samych podróży i ich przebiegu, lecz także uwypuklenie skutków kulturowych kobiecych peregrynacji ${ }^{120}$. Prac dedykowanych peregrynacjom kobiecym we wcześniejszych stuleciach jest zdecydowanie mniej ${ }^{121}$.

Wydaje się, że pewną rolę w odkrywaniu kulturowego wymiaru zagranicznych peregrynacji kobiecych w czasach saskich i stanisławowskich, i tym samym w pogłębianiu badań nad problematyką wojaży Polek w XVIII i na początku XIX w., odegrała również konferencja naukowa zorganizowana w listopadzie 2013 r. przez Pracownię Literatury Oświecenia w Instytucie Badań Literackich PAN wraz z Polskim Towarzystwem Badań nad Wiekiem Osiemnastym, której materiały rok później zredagowała Agata Roćko ${ }^{122}$. Tom pokonferencyjny zawiera 21 artykułów, z których cztery podejmują wprost problematykę podróżujących Polek ${ }^{123}$.

117 Stynne kobiety w Rzeczypospolitej XVIII wieku, red. A. Roćko, M. Górska, Warszawa 2017. Vide też: A. Eysiak-Łątkowska, Wptyw polskich arystokratek na aranżowanie matżeństw od drugiej potowy XVIII do początku XIX wieku, [w:] Historie nieobojętne, t. II (Kądziel - kotyska - toże. Atrybuty kobiecości na przestrzeni dziejów), red. A. Głowacka-Penczyńska, K. Grysińska-Jarmuła, M. Opioła-Cegiełka, Bydgoszcz 2017, s. 151-166.

118 Vide m.in.: T.K. Morawska z Radziwiłłów, Dziennik podróży europejskiej 1773-1774, wyd. B. Rok, Wrocław 2002.

119 Z licznych prac B. Roka, opublikowanych tylko w ostatnim dziesięcioleciu, można wymienić np.: Wyprawa Teofili Konstancji z Radziwittów Morawskiej do Neapolu w 1774 r., [w:] Klio viae et India. Opuscula Marco Cetwiński dedicata, red. A. Odrzywolska-Kidawa, Warszawa 2010, s. 521-527; idem, Europa drugiej potowy XVIII wieku w oczach polskiej podróżniczki Teofili Konstancji z Radziwittów Morawskiej, [w:] Europejski wiek oświecenia: uniwersalizm myśli, różnorodność dróg, red. M. Dębowski,

A. Grześkowiak-Krwawicz, M. Zwierzykowski, Kraków 2013, s. 221-233.

120 M.E. Kowalczyk, Zagraniczne podróże Polek w epoce oświecenia, Łomianki 2019.

121 J. Pietrzak, Siedemnastowieczna podróżniczka. Wrażenia Katarzyny z Sobieskich Radziwittowej z podrózy po Europie Zachodniej w latach 1677-1678, [w:] Kulturowe wzorce a spoteczna praktyka. Studia $z$ dziejów kobiet, red. A. Jakuboszczak, P. Matusik, Poznań 2012, s. 103-126.

122 Polski Grand Tour w XVIII i początkach XIX wieku, red. A. Roćko, Warszawa 2014.

123 Są to następujące teksty: A. Roćko, Grand Tour „Dam Modnych” (s. 131-150); B. Mazurkowa, Nowy Grand Tour w świetle „Mes Voyages” Walerii Tarnowskiej (s. 153-182); K. Jagiełło-Jakuboszczak, Portrety 
W dalszym ciągu zainteresowaniem głównie badaczek cieszyły się żeńskie zakony (zdecydowanie mniejszym bractwa religijne $\mathrm{z}$ ich udziałem) - od administracji, poprzez uposażenie, aż po rolę społeczną i ideologiczną. Tytułem przykładu należy tu wskazać gruntowne studium Olgi M. Przybyłowicz, traktujące o życiu codziennym klarysek w okresie późnego średniowiecza i renesansu ${ }^{124}$. Z kolei w ważnym opracowaniu zbiorowym, Klasztory mnisze na wschodnich terenach dawnej Rzeczypospolitej, pomieszczono także opracowania traktujące o zakonnych wspólnotach żeńskich autorstwa m.in. Małgorzaty Borkowskiej, Romana Pelczara i Bożeny Popiołek ${ }^{125}$. Niektóre z tych klasztorów, np. Karmelitanki Bose, doczekały się nawet osobnego uwypuklenia ich wkładu w kulturę i duchowość społeczeństwa polskiego w długim trwaniu ${ }^{126}$. W tym dorobku nie zabrakło również badań nad poszczególnymi klasztorami, m.in. norbertanek w Ibramowicach (Maria Dębowska) i z krakowskiego Zwierzyńca (Edyta Pluta), krakowskich klarysek (Patrycja Gąsiorowska) oraz bernardynek na ziemi wieluńskiej (praca zbiorowa) ${ }^{127}$. Pojawiły się też szkice osobno charakteryzujące grupę przełożonych bernardynek w Krakowie, a także funkcjonowanie we Lwowie środowiska miejscowych tercjarek dominikańskich ${ }^{128}$. Osobno wymienić trzeba książkę Jolanty Gwioździk, w której autorka postawiła nowe i ciekawe pytania dotyczące piśmienności, czytelnictwa i własnej twórczości mniszek w Polsce przedrozbiorowej ${ }^{129}$. W zakresie

polskich dam jako pamiątka ich Wielkich Podrózy (s. 187-198); R. Dampe-Jarosz, Wptyw wtoskich podróży na dziatalność Anny Amalii von Sachsen-Weimar-Eisenach i Izabeli Czartoryskiej (s. 201-214). Vide też: J. Dygdała, A. Kucharski, Podróż królewny Sobieskiej, a także kilka magnackich Grand Tour z XVII/ XVIII wieku w relacjach Samuela Szwykowskiego, „Czasy Nowożytne” 2014, t. XXVII, s. 31-58 (artykuł traktuje o Teresie Kunegundzie Sobieskiej, żonie elektora bawarskiego Maksymiliana II Emanuela).

124 O.M. Przybyłowicz, Reguta zakonna jest wozem do nieba. Realia życia w klasztorach klarysek od XIII do końca XVI w Matopolsce, Wielkopolsce i na Ślasku, Warszawa 2016.

125 M. Borkowska, Klasztory mniszek obrządku tacińskiego w Wielkim Księstwie Litewskim. Stan i problematyka badan, [w:] Klasztory mnisze na wschodnich terenach dawnej Rzeczypospolitej od XVI do poczatków XX wieku, red. J. Gwioździk, R. Witkowski, A.M. Wyrwa, Poznań 2014, s. 147-160; R. Pelczar, Zakon Benedyktynek na Rusi Czerwonej w XVI-XVIII w. Dynamika rozwoju i gtówne kierunki dziatalności, [w:] ibidem, s. 161-169. Cf. też ciekawie zasygnalizowane wybrane zagadnienia mentalności zakonnic: B. Popiołek, $W$ wielkim strachu i bojaźni rezydujem.... Mentalność zakonnic w okresie saskim. Próba sondażu, [w:] ibidem, s. 183-193.

126 Czterysta lat Karmelitanek Bosych $w$ Polsce. Wktad mniszek karmelitańskich w polska historię, kulture i duchowość. Księga Jubileuszowa, red. E. Buszewicz, A. Smagacz, Kraków 2014.

127 M. Dębowska, Klasztor norbertanek w Ibramowicach. Studia i materiaty, Lublin 2012; E. Pluta, Środowisko rodzinne krakowskich norbertanek ze Zwierzyńca - przyczynek do badań nad sktadem osobowym konwentów żeńskich (XVII-XVIII w.), „Klio” 2016, t. XXXIX, nr 4, s. 77-96; P. Gąsiorowska, Konwent Klarysek krakowskich do końca XVIII wieku. Studium prozopograficzne, Kraków 2015; vide recenzję E. Pluty, „Studia Historyczne” 2016, t. LIX, z. 1, s. 110-113; 400-lecie klasztoru sióstr bernardynek na ziemi wieluńskiej, red. J. Książek, T. Olejnik, Wieluń 2013.

128 P. Stefaniak, Dzieje tercjarek dominikańskich „de Poenitentia we Lwowie (1293-1740), „Nasza Przeszłość” 2014, t. CXXI, s. 75-102; H. Święch, Przetożone klasztoru bernardynek pw. św. Agnieszki w Krakowie w XV-XVIII wieku, „Nasza Przeszłość” 2015, t. CXXIII, s. 113-132.

129 J. Gwioździk, Kultura pisma i ksiażki w żeńskich klasztorach dawnej Rzeczypospolitej XVI-XVIII wieku, Katowice 2015; vide recenzję E. Pluty, „Res Gestae” 2016, t. III, s. 328-331. Cf. także: K. Kaczor- 
biografistyki zasłużonych zakonnic należy odnotować studia o Zofii Czeskiej (15841650), założycielce w Krakowie pierwszej szkoły dla dziewcząt z ubogich rodzin, i Magdalenie Mortęskiej (1554-1631), ksieni klasztoru benedyktynek w Chełmnie ${ }^{130}$.

O codziennych realiach gospodarowania, nierzadko trudnych ze względu na sytuację gospodarczą i polityczną oraz popularność danego klasztoru, polskich mniszek pisały Patrycja Gąsiorowska, Olga M. Przybyłowicz i Anna Szylar ${ }^{131}$. Niewiele natomiast powstało prac o bractwach religijnych przy klasztorach żeńskich, na co zwróciła uwagę ostatnia $\mathrm{z}$ wymienionych ${ }^{132}$. O trudnych losach monasterów bazylianek w Galicji po upadku Rzeczypospolitej pisała Olga Duch ${ }^{133}$. Na rynku pojawiły się też wydawnictwa źródłowe do dziejów niektórych żeńskich klasztorów i samych mniszek ${ }^{134}$.

Omówienie najnowszych osiągnięć polskiej historiografii poświęconej dziejom kobiet w państwie polsko-litewskim do 1795 r. nie może pomijać tak ważnej problematyki, jaką jest mentalność i wzorce osobowe. Wymienić tu trzeba monografię Urszuli Kicińskiej o wzorcu szlachcianki w okresie baroku powstałą na podstawie oracji

-Scheitler, Dziatalność pisarska polskich zakonów żeńskich w dobie baroku, „Acta Universitatis Lodziensis. Folia Litteraria Polonica” 2013, t. XIII, s. 77-89.

130 Btogostawiona Matka Zofia Czeska (1584-1650). Prekursorka integralnego wychowania dzieci i mtodzieży, red. J. Machnia, R. Gąsior, Kraków 2014; K.Ż. Sztylc, The Abbas Magdalena Mortęska (15541631). Her life and reformist initiatives aimed at female education in the post-tridentine era, „Roczniki Teologiczne" 2016, t. LXIII, z. 4, s. 53-73; M. Borkowska, Uwagi o niektórych aspektach biografii Magdaleny Mortęskiej, „Nasza Przeszłość” 2017, t. CXXVII, s. 81-107.

131 P. Gąsiorowska, Obrót gotówka w klasztorze żeńskim na przyktadzie osiemnastowiecznych ksiag rachunkowych wybranych klasztorów krakowskich i lwowskich, [w:] Klasztor w gospodarce średniowiecznej i nowożytnej, red. M. Derwich, Wrocław 2013, s. 301-318; O.M. Przybyłowicz, Jak panny zakonne rozliczaty się? Księgi rachunkowe jako źródto do badań nad polskimi klasztorami żeńskimi w XVI-XVIII w., [w:] ibidem, s. 105-108; eadem, Klasztor klarysek w Strzelnie - uposażenie, darowizny, dochody. Przyczynek do standardu życia wspólnoty w świetle prawa zakonnego i dokumentów, „Śląski Kwartalnik Historyczny Sobótka” 2016, t. LXXI, nr 2, s. 19-46; eadem, Źródta do poznania gospodarki w dobrach wiejskich klarysek gnieźnieńskich od końca XVI do schytku XVII stulecia, „Kwartalnik Historii Kultury Materialnej” 2017, t. LXV, nr 4, s. 447-459; A. Szylar, Sprawa o tym, jak benedyktynki gospodarstwo prowadzity.... Organizacja i funkcjonowanie gospodarki opactwa benedyktynek $w$ Sandomierzu $w$ XVII iXVIII w., [w:] Klasztor w gospodarce..., s. 447-459; eadem, Potrzeby do pożytku należace - rozrzutność czy skapstwo? O wydatkach mniszek w XVIII wieku w ksiegach ekspensy, [w:] Kobieta i mężczyzna..., s. 345-356.

132 A. Szylar, Bractwa religijne przy klasztorach żenskich XVIII wieku, [w:] Bractwa religijne w średniowieczu i w okresie nowożytnym (do końca XVIII wieku), red. D. Burdzy, B. Wojciechowska, Kielce 2014, s. 167-182. Vide też: A. Jabłońska, The Presence and Role of Women in Old (Age) Polish Confraternities (the Case Study of the Archdeaconry of Gniezno in the 17 th Century), [w:] Kobieta niepoznana..., s. 161-177.

133 O. Duch, Losy monasterów bazylianek w Galicji na przetomie XVIII i XIX w., [w:] Kasaty klasztorów na obszarze dawnej Rzeczypospolitej Obojga Narodów i na Ślasku na tle procesów sekularyzacyjnych w Europie, red. M. Derwich, t. I (Geneza Kasaty na ziemiach zaboru austriackiego i rosyjskiego), Wrocław 2014, s. 233-247.

134 Z. Grothówna, Kronika klasztoru sióstr bernardynek w Imbramowicach 1703-1741, wyd. W. Bielak, W. Żurek, Kielce 2011; Żywoty matki Barbary od Najśw. Sakramentu (Zadzikowej) karmelitanki bosej (1609-1670), oprac. C. Gil, Kraków 2013. 
pogrzebowych ${ }^{135}$. W tym nurcie idealnego modelu kobiety w funeralnej literaturze okolicznościowej (tym razem chodzi o magnatkę i protestantkę Elżbietę z Szydłowieckich Radziwiłłową) sytuują się rozprawki Dariusza Chemperka ${ }^{136}$. Filip Wolański z kolei zwrócił uwagę na niejednoznaczny obraz kobiety, jak można byłoby tego oczekiwać, występujący w kaznodziejstwie bernardyńskim epoki saskiej ${ }^{137}$. Wspomnieć też należy o książce Beaty Stuchlik-Surowiak, w której autorka podważyła dotychczasowe ustalenia historiografii na temat utworów okolicznościowych heraldyka i poety Bartosza Paprockiego, klasyfikowanych do tej pory jako twórczość „antyfeministyczna” ${ }^{138}$.

Natomiast opracowanie Urszuli Świderskiej-Włodarczyk, mające być odejściem od tradycyjnych paradygmatów i nowym odczytaniem wzorów osobowych szlachty w Polsce czasów renesansu i baroku, całkowicie pomija ów wzorzec w odniesieniu do żon, córek i sióstr, mimo że autorka raz po raz akcentuje wartość i rolę rodziny w życiu szlachty ${ }^{139}$. Nie brakuje również innych przyczynków podejmujących próbę nakreślenia ówczesnych modeli kobiety, wyłaniających się chociażby z analiz mów weselnych, twórczości śpiewanej, poradników gospodarczych i dobrego życia ${ }^{140}$.

W zakresie historii kultury i mentalności kobiecej jesteśmy jeszcze bardzo odlegli od całościowego opracowania. Tym bardziej należy zwrócić uwagę na szerokie spektrum możliwości analitycznych piśmiennictwa kobiecego wobec różnorodności poruszanej

135 U. Kicińska, Wzorzec szlachcianki w polskich drukowanych oracjach pogrzebowych XVII wieku, Warszawa 2013.

136 D. Chemperek, Kalwińska święta. Elżbiety z Szydtowieckich Radziwittowej ars bene vivendi w „Krótkim wypisaniu sprawy" Cypriana Bazylika, [w:] Ars bene vivendi. Studia ofiarowane Profesorowi Maciejowi Wtodarskiemu w 70. rocznice urodzin, red. E. Buszewicz, L.L. Grzybowska, Kraków 2017, s. 273-290; idem, Elżbieta Radziwittowa - święta pani Cypriana Bazylika "Krótkie wypisanie sprawy" jako ewangelicka „ars bene moriendi", [w:] Z historii kultury staropolskiej..., s. 189-203. Vide ponadto: M. Krzysztofik, Siedemnastowieczna refleksja o rolach kobiety i mężczyzny w matżeństwie (na podstawie kazań pogrzebowych), „Res Gestae” 2016, t. III, s. 5-18.

137 F. Wolański, Rozważne Panny i Dzielni Kawalerowie. Kulturowy status ptci w bernardyńskim dyskursie kaznodziejskim epoki saskiej, [w:] Kobieta i mężczyzna..., s. 493-501.

138 B. Stuchlik-Surowiak, Obraz matżenstwa w antyfeministycznych utworach Bartosza Paprockiego na tle obyczajowych, religijnych oraz literackich zjawisk XVI i pierwszej potowy XVII wieku, Katowice 2016.

139 U. Świderska-Włodarczyk, Homo Nobilis. Wzorzec szlachcica w Rzeczypospolitej w XVI i XVII wieku, Warszawa 2017; vide recenzje A. Klonder, „Kwartalnik Historii Kultury Materialnej” 2018, t. LXVI, nr 1, s. 111-114 i U. Augustyniak, „Kwartalnik Historyczny” 2020, t. CXXVII, nr 2, s. 400-409. Urszula Świderska jest także autorką szkicu Szlachecki wzorzec osobowy gospodyni w Polsce przetomu średniowiecza i czasów renesansu, [w:] Kobieta w gospodarstwie domowym. Ziemie polskie na tle porównawczym, red. K. Sierakowska, G. Wyder, Zielona Góra 2012, s. 21-27, który jednak niewiele wnosi do rozpatrywanego zagadnienia, jeżeli ktoś zapoznał się z wcześniejszą o 20 lat pracą A. Wyrobisza, Staropolskie wzorce rodziny i kobiety - żony i matki, „Przegląd Historyczny” 1992, t. LXXXIII, z. 3 , s. $405-421$.

140 A. Jakuboszczak, Żona doskonata. Obraz kobiety w staropolskich mowach weselnych ze zbiorów PAN Biblioteki Kórnickiej, [w:] Historie nieobojętne..., t. II, s. 63-75; A.M. Jabłońska, Obraz kobiety w twórczości śpiewanej okresu staropolskiego, „In Gremium” 2011, t. VI, s. 41-64; A. Korczyńska, Rola i pozycja kobiety w staropolskich ekonomikach, „In Gremium” 2016, t. X, s. 75-86; B. Rok, Wyobrażenie mężczyzny i kobiety w staropolskich poradnikach artis bene vivendi, [w:] Kobieta i mężczyzna..., s. 483-492. 
problematyki przez autorki wywodzące się z rozmaitych sfer, z różnym poziomem wykształcenia i przygotowania do pełnienia ról społecznych, o czym przekonuje nas lektura artykułów pomieszczonych w tomie poświęconym kobiecej epistolografii ${ }^{141}$.

\section{Uwagi końcowe}

Oceniając całość osiągnięć badawczych w zakresie historii kobiet na ziemiach polskich we wczesnej epoce nowożytnej, można z zadowoleniem stwierdzić ich dalszy rozwój w sensie przyrostu i liczby prac oraz poruszanej problematyki. W tych osiągnięciach oprócz historyków mają też swój udział historycy piśmiennictwa, historii medycyny, antropologii kulturowej i socjologii. Trudniej jest określić, w których obszarach problematyki kobiecej nastąpiła największa rozbudowa tematyczna i postęp w zakresie stosowanych metod, zwłaszcza że w tym dorobku znajduje się cała masa prac drobnych. Choć każda próba oceny jest zawsze subiektywna, to wydaje się, że obecnie najwięcej wiemy o kobietach funkcjonujących w ramach najmniejszej grupy społecznej, jaką stanowiła rodzina, a więc o ich rolach, pozycji prawno-społecznej i ekonomicznej jako żon i matek oraz - co warto podkreślić - o ich prokreacji, najmniej zaś o kobietach samotnych. Lepiej też zostało rozpoznane zarządzanie przez nie dworem magnackim i sprawowanie funkcji patronackich oraz budowanie więzi klientalnych. Jednak dwa podstawowe etapy w życiu kobiet, czyli dzieciństwo (włączając w to edukację domową) i starość nadal czekają na dokładniejsze charakterystyki. Ciągle niewiele wiemy o chorobach wieku dziecięcego, podobnie jak o uwarunkowaniach kondycji zdrowotnej dorosłych Polek w różnych grupach społecznych, z uwypukleniem „chorób kobiecych” i o podłożu nerwicowym. Na poważniejsze zainteresowanie badawcze czeka niemała grupa mamek i piastunek zatrudnianych przez familie szlacheckie i elitę mieszczańską. Nadal w powijakach tkwią studia nad ciałem kobiety we wszystkich okresach jej życia, ciałem obnażonym i zakrytym, ale niekoniecznie będącym źródłem męskiego (i kobiecego) pożądania, nad wpływem wysiłku fizycznego na jego funkcjonowanie, nad ćwiczeniem fizycznym i duchowym ciała oraz jego zdeformowaniem (ciało niepełnosprawne, okaleczone).

Nie do końca satysfakcjonują dość liczne ostatnio prace poświęcone uroczystościom rodzinnym (ślubne i weselne, chrzestne i pogrzebowe), które często są oparte na skromnej podstawie źródłowej, toteż w większym zakresie wzbogacają od strony faktograficznej znany nam już obraz ich przebiegu i znaczenia w życiu rodzinnym niż wysuwają nowe pytanie badawcze. Tylko tytułem przykładu można wskazać, że epatowanie nawet kilkunastoma przykładami występowania kobiet w roli matek chrzestnych, począwszy od środowiska wiejskiego, a na kręgach magnackich skończywszy, ma dość ograniczoną wartość poznawczą. Tymczasem zastosowanie do ich obserwacji,

${ }^{141}$ Kobiece kregi korespondencyjne... 
także np. relacji towarzyskich w społecznościach wsi, miasteczek i grup sąsiedzkich, metody analizy sieci społecznych (Social Network Analysis - SNA), zaproponowanej przez socjologów i z powodzeniem stosowanej już w zachodniej nauce historycznej, daje możliwość uchwycenia procesów, które nierzadko nie są widoczne przy zastosowaniu jedynie tradycyjnych technik obserwacji historycznej. Zastosowanie SNA, co ważne, umożliwia określenie wpływu nie jednego czy dwóch, lecz kilku różnych czynników na kształtowanie się struktur społecznych z udziałem kobiet.

Luki badawcze w historii kobiet w okresie staropolskim, mimo że z pewnością nie brakuje ich także w odniesieniu do dwóch następnych stuleci, nie powinny być usprawiedliwieniem przed niepodejmowaniem próby napisania naukowej syntezy dziejów kobiet na ziemiach polskich. Przy wszystkich niedostatkach tego typu ujęć mogłaby ona nie tylko stanowić podsumowanie dotychczasowej wiedzy, lecz także być inspiracją i zachętą do rozbudowy katalogu pytań oraz metod badawczych.

\section{Bibliografia (Bibliography)}

\section{Źródła drukowane}

Augustyniak U., Testamenty ewangelików reformowanych w Wielkim Księstwie Litewskim w XVI-XVIII wieku, Warszawa 2014.

Codzienne ktopoty, wielkie interesy i podwójna elekcja. Korespondencja radziwittowskich urzędników z księżna Anna z Sanguszków Radziwittowa i jej synem Michatem Kazimierzem 1733/1734, wyd. J. Dygdała, Warszawa 2013.

Czartoryska z Flemmingów I., Podróż po Anglii. Dziennik z podróży po Anglii i Szkocji w roku 1790, oprac. i wprowadzenie A. Whelan, przekł. z jęz. franc. Z. Żygulski, A. Whelan, Warszawa 2015.

Dtug śmiertelności wyptacić potrzeba. Wybór testamentów mieszczan krakowskich z XVII-XVIII wieku, oprac. E. Danowska, Kraków 2011.

„Gdybym Cię, moje Serce, za męża nie miata, żyć bym nie mogta”. Listy Magdaleny z Czapskich do Hieronima Floriana Radziwitta z lat 1744-1759, wstęp i oprac. I. Maciejewska, K. Zawilska, Olsztyn 2016.

Grothówna Z., kronika klasztoru sióstr bernardynek w Imbramowicach 1703-1741, wyd. W. Bielak, W. Zurek, Kielce 2011.

Katalogi testamentów mieszkańców miast z terenów Korony i Wielkiego księstwa Litewskiego do 1795 roku, t. I (Testamenty $w$ ksiegach miejskich wilenskich z XVI-XVII wieku. Katalog), oprac. K. Frejlich, Warszawa 2017.

Katalogi testamentów mieszkańców miast z terenów Korony i Wielkiego księstwa Litewskiego do 1795 roku, t. II (Testamenty mieszkańców miast Wotynia od końca XVI - do początku XVIII wieku. Katalog), oprac. N. Biłous, Warszawa 2017. 
Katalogi testamentów mieszkańców miast z terenów Korony i Wielkiego księstwa Litewskiego do 1795 roku, t. III (Katalog testamentów mieszkańców Brześcia i Grodna od XVI do początku XVIII wieku), oprac. N. Sliž, Warszawa 2017.

Katalogi testamentów mieszkańców miast z terenów Korony i Wielkiego księstwa Litewskiego do 1795 roku, t. IV (Testamenty mieszkańców lwowskich z drugiej potowy XVI i z XVII wieku. Katalog), oprac. O. Winnyczenko, Warszawa 2017.

Katalogi testamentów mieszkańców miast z terenów Korony i Wielkiego księstwa Litewskiego do 1795 roku, t. V (Testamenty z ksiag sądowych matych miast polskich do 1525 roku), oprac. A. Bartoszewicz, Warszawa 2017.

Katalogi testamentów mieszkańców miast z terenów Korony $i$ Wielkiego księstwa Litewskiego do 1795 roku, t. VI (Katalog testamentów z krakowskich ksiag miejskich do 1550 roku), oprac. J. Wysmułek, Warszawa 2017.

Katalogi testamentów mieszkańców miast z terenów Korony i Wielkiego księstwa Litewskiego do 1795 roku, t. VII (Katalog testamentów poznańskich z drugiej polowy XVI i z XVII wieku), oprac. A. Karpiński, Warszawa 2017.

Korespondencja Elżbiety z Lubomirskich Sieniawskiej kasztelanowej krakowskiej, oprac. i wyd. B. Popiołek, U. Kicińska, A. Słaby, t. I ( $Z$ serca kochająca żona i uniżona stuga. Listy Elżbiety $z$ Lubomirskich Sieniawskiej do męża Adama Mikotaja Sieniawskiego z lat 1688-1726), Warszawa-Bellerive-sur-Allier 2016.

Korespondencja Elżbiety z Lubomirskich Sieniawskiej kasztelanowej krakowskiej, oprac. i wyd. B. Popiołek, U. Kicińska, A. Słaby, t. II (Jaśnie Oświecona Mościa Księżno Dobrodziejko. Informatorzy i urzędnicy), Warszawa-Bellerive-sur-Allier 2016.

Korespondencja Elżbiety z Lubomirskich Sieniawskiej kasztelanowej krakowskiej, oprac. i wyd. B. Popiołek, U. Kicińska, A. Słaby, t. III (Jaśnie Oświecona Mościa Księżno Dobrodziejko. Rodzina, przyjaciele i klienci), Warszawa-Bellerive-sur-Allier 2016.

Listy Jakuba Kazimierza Rubinkowskiego do Elżbiety z Lubomirskich Sieniawskiej (1716-1726), oprac. K. Maliszewski, A. Kucharski, Torun 2017.

Łopatecki K., Kupczewska M., Testament Izabeli z Poniatowskich Branickiej (3 XI 1805 r.), „Kwartalnik Historii Kultury Materialnej” 2016, t. LXIV, nr 1, s. 103-109.

Massalska A.H., Mémoires d’une écolière à l Abbaye-aux-Bois à Paris (1771-1779), éd. M.E. Kowalczyk, A. Locher, Mielec 2014.

Massalska A.H., Pamiętniki pensjonarki. Zapiski z czasów edukacji w Paryżu (1771-1779), wstęp. i oprac. M.E. Kowalczyk, przekł. z jęz. franc. A. Pikor-Półtorak, Kraków 2012.

Morawska z Radziwiłłów T.K., Dziennik podróży europejskiej 1773-1774, oprac. B. Rok, Wrocław 2002.

Ojcowskie synom przestrogi. Instrukcje rodzicielskie (XVI-XVII w.), wstęp i objaśnienia D. Żołądź-Strzelczyk, M.E. Kowalczyk, Wrocław 2017.

Platerowa z Sosnowskich K., Moja podróż do Wtoch. Dziennik z lat 1785-1786, wstęp i oprac. M.E. Kowalczyk, przekł. z jęz. franc. A. Pikor-Półtorak, Łomianki 2013.

Popiołek B., Testament Magdaleny z Tartów Lubomirskiej, wojewodziny krakowskiej, „Krakowskie Studia Małopolskie" 2013, nr XVIII, s. 423-433. 
Przestrogi i nauki dla dzieci. Instrukcje rodzicielskie (XVIII w.), wstęp i objaśnienia D. Żołądź-Strzelczyk, M.E. Kowalczyk, Wrocław 2017.

Testament mieszczanki żarnowskiej Agnieszki Frejeckiej z 1755 r., wyd. S. Kazusek, „Między Wisłą a Pilicą" 2014, t. XV, s. 127-135.

Testamenty chtopów polskich od drugiej potowy XVI do XVIII wieku, oprac. i wyd. J. Łossowski, Lublin 2015.

Testamenty książąt Lubartowiczów-Sanguszków. Wybór tekstów źródtowych z lat 1750-1876, oprac. J.M. Marszalska, W. Graczyk, Kraków 2011.

Testamenty szlacheckie z ksiag grodzkich wielkopolskich z lat 1631-1655, wyd. P. Klint, Wrocław 2008.

Testamenty szlacheckie z ksiag grodzkich wielkopolskich z lat 1657-1680, wyd. P. Klint, Wrocław 2011.

Testamenty szlacheckie z ksiag grodzkich wielkopolskich z lat 1681-1700, wyd. P. Klint, Wrocław 2015.

Testamenty szlachty Prus Królewskich z XVII wieku, wyd. J. Kowalkowski, W. Nowosad, Warszawa 2013.

Testamenty szlachty Prus Królewskich z XVIII wieku, wyd. J. Kowalkowski, W. Nowosad, Warszawa 2016.

„Wszyscy śmiertelni jesteśmy i dlatego rozrządzamy majętności swoje”. Wybór testamentów z ksiag miejskich województwa sandomierskiego (XVI-XVIII wiek), oprac. K. Justyniarska-Chojak, Kielce 2014.

Żyoty matki Barbary od Najśw. Sakramentu (Zadzikowej) karmelitanki bosej (1609-1670), oprac. C. Gil, Kraków 2013.

\section{Opracowania}

400-lecie klasztoru sióstr bernardynek na ziemi wieluńskiej, red. J. Książek, T. Olejnik, Wieluń 2013.

„Annales de Démographie Historique” 1981.

Augustyniak U. (rec.), U. Świderska-Włodarczyk, Homo Nobilis. Wzorzec szlachcica w Rzeczypospolitej w XVI i XVII wieku, Warszawa 2017, „Kwartalnik Historyczny” 2020, t. CXXVII, nr 2, s. 400-409.

Btogostawiona Matka Zofia Czeska (1584-1650). Prekursorka integralnego wychowania dzieci i mtodzieży, red. J. Machnia, R. Gąsior, Kraków 2014.

Bobryk W., Popadie i popówny - żony i córki kaptanów unickich w XVIII wieku, [w:] Per mulierem... Kobieta $w$ dawnej Polsce - wśredniowieczu i dobie staropolskiej, red. K. Justyniarska-Chojniak, S. Konarska-Zimnicka, Warszawa 2012, s. 205-210.

Bogucka M., Rodzina w polskim mieście XVI-XVII w. Wprowadzenie w problematykę, „Przegląd Historyczny" 1983, t. LXXIV, z. 3, s. 495-507.

Borkowska M., Klasztory mniszek obrządku tacińskiego w Wielkim Ksiestwie Litewskim. Stan i problematyka badań, [w:] Klasztory mnisze na wschodnich terenach dawnej Rzeczypospolitej od XVI do początków XX wieku, red. J. Gwioździk, R. Witkowski, A.M. Wyrwa, Poznań 2014, s. 147-160. 
Borkowska M., Uwagi o niektórych aspektach biografii Magdaleny Mortęsiej, „Nasza Przeszłośc” 2017, t. CXXVII, s. 81-107.

Burdzy A., Aktywność gospodarcza i kulturalna kobiet w Sandomierzu w XVI wieku, [w:] Per mulierem... Kobieta $w$ dawnej Polsce - w'średniowieczu i dobie staropolskiej, red. K. Justyniarska-Chojniak, S. Konarska-Zimnicka, Warszawa 2012, s. 249-259.

Burdzy D., Perypetie matżeńskie mieszczan sandomierskich w XVI wieku, [w:] Kobieta i mężczyzna: jedna przestrzeń - dwa światy, red. B. Popiołek, A. Chłosta-Sikorska, M. Gadocha, Warszawa 2015, s. 37-46.

Chemperek D., Elżbieta Radziwittowa - „święta pani”. Cypriana Bazylika „Krótkie wypisanie sprawy” jako ewangelicka ,ars bene moriendi”, [w:] Z historii kultury staropolskiej. Studia ofiarowane Urszuli Augustyniak, red. A. Bartoszewicz, A. Karpiński, M. Ptaszyński, A. Zakrzewski, Warszawa 2020, s. 189-203.

Chemperek D., Kalwińska święta. Elżbiety z Szydtowieckich Radziwittowej ars bene vivendi $w$ „Krótkim wypisaniu sprawy” Cypriana Bazylika, [w:] Ars bene vivendi. Studia ofiarowane Profesorowi Maciejowi Wtodarskiemu w 70. rocznice urodzin, red. E. Buszewicz, L.L. Grzybowska, Kraków 2017, s. 273-290.

Ciszewska M., Tuliusz domowy. Świeckie oratorstwo szlacheckie kręgu rodzinnego (XVII-XVIII wieku), Warszawa 2016.

Conjux, mater, flia, soror propinqua, civis... Kobieta na ziemi wschowskiej i pograniczu wielkopolsko-śląskim, red. M. Małkus, K. Szymańska, Wschowa-Leszno 2016.

Czarniecka A., Królowa wdowa w polityce, [w:] Maria Kazimiera Sobieska (1641-1716). Wkręgu rodziny, polityki i kultury, red. A. Kalinowski, P. Tyszka, Warszawa 2017, s. 149-165.

Czterysta lat Karmelitanek Bosych w Polsce. Wktad mniszek karmelitanskich w polska historię, kulturę i duchowość. Księga Jubileuszowa, red. E. Buszewicz, A. Smagacz, Kraków 2014.

Dampe-Jarosz R., Wptyw wtoskich podróży na dziatalność Anny Amalii von Sachsen-Weimar-Eisenach i Izabeli Czartoryskiej, [w:] Polski Grand Tour w XVIII i poczatkach XIX wieku, red. A. Roćko, Warszawa 2014, s. 201-214.

Delimata M., Prawo rodzinne w pracach Barttomieja Groickiego (okoto 1534-1606), [w:] Spoteczeństwo staropolskie. Seria nowa, t. III (Spoteczeństwo a rodzina), red. A. Karpiński, Warszawa 2011, s. 21-36.

Delimata-Proch M., Ciąża, poród oraz potóg w świetle polskich ksiag cudów i task (od średniowiecza do XVIII w., „Kwartalnik Historii Kultury Materialnej” 2015, t. LXIII, nr 3, s. 433-449.

Dębowska M., Klasztor norbertanek w Ibramowicach. Studia i materiaty, Lublin 2012.

Dubas-Urwanowicz E., O prawie w świecie kobiet w Rzeczypospolitej w XVI-XVII wieku, [w:] Kobieta i mężczyzna: jedna przestrzeń - dwa światy, red. B. Popiołek, A. Chłosta-Sikorska, M. Gadocha, Warszawa 2015, s. 51-72.

Dubas-Urwanowicz E., Panie Zborowskie w XVI wieku, [w:] Z historii kultury staropolskiej. Studia ofiarowane Urszuli Augustyniak, red. A. Bartoszewicz, A. Karpiński, M. Ptaszyński, A. Zakrzewski, Warszawa 2020, s. 323-331. 
Duch O., Losy monasterów bazylianek w Galicji na przetomie XVIII i XIX w., [w:] Kasaty klasztorów na obszarze dawnej Rzeczypospolitej Obojga Narodów i na Ślasku na tle procesów sekularyzacyjnych w Europie, red. M. Derwich, t. I (Geneza Kasaty na ziemiach zaboru austriackiego i rosyjskiego), Wrocław 2014, s. 233-247.

Duży W., Wspomnienia o zmartych rodzicach $w$ wybranych zapiskach pamiętnikarskich z przetomu XVIII i XIX wieku, [w:] Nie wszystek umrę. Pamięć o zmartych w kulturze staropolskiej, red. A. Jankowska, A. Klonder, Bydgoszcz 2015, s. 271-281.

Dygdała J. (rec.), A. Słaby, Rządzicha oleszycka. Dwór Elżbiety z Lubomirskich Sieniawskiej jako przyktad patronatu kobiecego w czasach saskich, Kraków 2014, „Czasy Nowożytne” 2015, t. XXVIII, s. 238-242.

Dygdała J., Kucharski A., Podróż królewny Sobieskiej, a także kilka magnackich Grand Tour z XVII/XVIII wieku w relacjach Samuela Szwykowskiego, „Czasy Nowożytne” 2014, t. XXVII, s. 31-58.

Dziatalność Elżbiety z Lubomirskich Sieniawskiej. Polityka - gospodarka - kultura, red. B. Popiołek, Warszawa 2020.

Dzieje kobiet w Polsce. Dyskusja wokót przysztej syntezy, red. K.A. Makowski, Poznań 2014.

Gąsiorowska P., Konwent Klarysek krakowskich do końca XVIII wieku. Studium prozopograficzne, Kraków 2015.

Gąsiorowska P., Obrót gotówką w klasztorze żeńskim na przyktadzie osiemnastowiecznych ksiag rachunkowych wybranych klasztorów krakowskich i lwowskich, [w:] Klasztor w gospodarce średniowiecznej i nowożytnej, red. M. Derwich, Wrocław 2013, s. 301-318.

Girsztowt A., Kobiety na elblaskim rynku renty w okresie średniowiecznym, „Komunikaty Mazursko-Warmińskie" 2013, nr 281, s. 481-498.

Głowacka-Penczyńska A., Spotkanie z katem. Mieszkanki matych miast Wielkopolski i Kujaw przed sadem $w$ drugiej potowie XVI i $w$ XVII wieku, [w:] Per mulierem... Kobieta $w$ dawnej Polsce - wśredniowieczu i dobie staropolskiej, red. K. Justyniarska-Chojniak, S. Konarska-Zimnicka, Warszawa 2012, s. 299-309.

Gołaszewski Ł. (rec.), Katalogi testamentów mieszkańców miast z terenów Korony i Wielkiego Księstwa Litewskiego do 1795 roku, Warszawa 2017: t. 1, Testamenty w ksiegach miejskich wileńskich z XVI i XVII wieku. Katalog, opr. Kamil Frejlich, ss. 100; t. 2, Testamenty mieszkańców miast Wotynia od końca XVI - do początku XVIII wieku. Katalog, opr. Natalia Biłous, ss. 134; t. 3, Katalog testamentów mieszkańców Brześcia i Grodna od XVI do początku XVIII wieku, opr. Natallia Sliž, ss. 78; t. 4, Testamenty mieszkańców lwowskich z drugiej potowy XVI i z XVII wieku. Katalog, opr. Oksana Winnyczenko, ss. 382; t. 5, Testamenty z ksiag sadowych matych miast polskich do 1525 roku, opr. Agnieszka Bartoszewicz, Krzysztof Mrozowski, Maciej Radomski, Katarzyna Warda pod red. A. Bartoszewicz, ss. 185; t. 6, Katalog testamentów z krakowskich ksiag miejskich do 1550 roku, opr. Jakub Wysmułek, ss. 384; t. 7, Katalog testamentów poznańskich z drugiej polowy XVI i z XVII wieku, opr. Andrzej Karpiński, ss. 435, „Czasopismo Prawno-Historyczne” 2019, t. LXXI, z. 2, s. 335-349.

Grześkowiak R., Amor curiosum. Studia o osobliwych tematach dawnej poezji erotycznej, Warszawa 2013. 
Grześkowiak R., O dupie Maryni. Rozwiązywanie „Gadki” Jana Kochanowskiego, „Odrodzenie i Reformacja w Polsce” 2016, t. LX, s. 111-141.

Guzowski P., Agnieszka - sottysowa z Krościenka Wyżnego, [w:] Grancie i pogranicza. Mikrohistorie i historie życia codziennego, red. P. Guzowski, M. Liedke, M. Ocytko, Kraków 2011, s. 39-54.

Guzowski P., Demografia rodziny szlacheckiej w świetle najnowszych badań genealogicznych, „Przeszłość Demograficzna Polski” 2011, t. XXX, s. 7-23.

Guzowski P., Rodzina szlachecka $w$ Polsce przedrozbiorowej. Studium demograficzne, Białystok 2019.

Gwioździk J., Kultura pisma i książi w ̇̇éskich klasztorach dawnej Rzeczypospolitej XVI-XVIII wieku, Katowice 2015.

Histoire des femmes en Occident, éd. G. Duby, M. Perrot, vol. I-V, Paris 1991-1992.

Hufton O., The Prospect before her: A History of Women in Western Europe, vol. I (1500-1800), Londres 1995.

Jabłońska A.M., Obraz kobiety w twórczości śpiewanej okresu staropolskiego, „In Gremium” 2011, t. VI, s. 41-64.

Jabłońska A., The Presence and Role of Women in Old (Age) Polish Confraternities (the Case Study of the Archdeaconry of Gniezno in the $17^{\text {th }}$ Century), [w:] Kobieta niepoznana na przestrzeni dziejów, red. A. Obara-Pawłowska, A. Miączewska, D. Wróbel, Lublin 2017, s. 161-177.

Jagiełło-Jakuboszczak K., Portrety polskich dam jako pamiątka ich Wielkich Podróży, [w:] Polski Grand Tour w XVIII i początkach XIX wieku, red. A. Roćko, Warszawa 2014, s. 187-198.

Jakuboszczak A., Aktywność polityczna wielkopolskich szlachcianek w XVIII wieku, [w:] Drogi kobiet do polityki (na przestrzeni XVIII-XXI wieku), red. T. Kulak, M. Dajnowicz, Wroclaw 2016, s. 45-58.

Jakuboszczak A., Kobieta morderczyni. Sprawa o mężobójstwo na przyktadzie osiemnastowiecznego procesu Konstancji Dobrowolskiej, [w:] Per mulierem... Kobieta w dawnej Polsce w średniowieczu i dobie staropolskiej, red. K. Justyniarska-Chojniak, S. Konarska-Zimnicka, Warszawa 2012, s. 311-317.

Jakuboszczak A., Rodzina i rodzinność szlachcianek wielkopolskich w XVIII wieku. Perspektywa kobieca, Poznań 2016.

Jakuboszczak A., Żona doskonata. Obraz kobiety w staropolskich mowach weselnych ze zbiorów PAN Biblioteki Kórnickiej, [w:] Historie nieobojętne, t. II (Kądziel - kotyska - toże. Atrybuty kobiecości na przestrzeni dziejów), red. A. Głowacka-Penczyńska, K. Grysińska-Jarmuła, M. Opioła-Cegiełka, Bydgoszcz 2017, s. 63-75.

Janicki K., Damy ztotego wieku, Kraków 2014.

Jankowski A., Patronka cywilizacyjnej przemiany. Biata legenda Marianny Skórzewskiej (1741-1773) wykreowana $w$ dobie upadku Rzeczypospolitej „Kwartalnik Historii Kultury Materialnej” 2014, t. LXII, nr 2, s. 227-241.

Jędrzejewski P., Wyklęci przez spoteczeństwo. Codzienność ludzi marginesu krakowskiego zespotu miejskiego w 2 potowie XVIII wieku, [w:] Dom, codzienność i święto. Ceremonie i tradycje 
rodzinne. Studia historyczno-antropologiczne, red. B. Popiołek, A. Chłosta-Sikorska, M. Gadocha, Kraków 2018, s. 151-164.

Justyniarska-Chojak K., Dziecko w rodzinie mieszczańskiej $w$ XVI-XVIII wieku w świetle przepisów prawa magdeburskiego (pomiędzy norma a praktyka), [w:] Dzieciństwo i starość w ujęciu historyków, red. A. Obara-Pawłowska, M. Kołacz-Chmiel, Lublin 2016, s. 243-266.

Justyniarska-Chojak K., „Najlepszemu i najściślejszemu przyjacielowi...” - więzi matżeńskie w testamentach mieszczańskich z terenu Matopolski w XVI wieku, [w:] Kobieta i mężczyzna: jedna przestrzeń - dwa światy, red. B. Popiołek, A. Chłosta-Sikorska, M. Gadocha, Warszawa 2015, s. 73-82.

Justyniarska-Chojak K., Troska o zdrowie kobiet w polskich zielnikach z XVI wieku, [w:] Per mulierem... Kobieta w dawnej Polsce - wśredniowieczu i dobie staropolskiej, red. K. Justyniarska-Chojniak, S. Konarska-Zimnicka, Warszawa 2012, s. 407-420.

Kaczor-Scheitler K., Dziatalność pisarska polskich zakonów żeńskich w dobie baroku, „Acta Universitatis Lodziensis. Folia Litteraria Polonica” 2013, t. XIII, s. 77-89.

Kamler M., Przemoc między szlachta sieradzkq w XVII wieku. Opis zjawiska, Warszawa 2011.

Kamler M., Przemoc między szlachta $w$ Polsce $w$ XVII w. - zjawisko masowe?, „Kwartalnik Historyczny" 2104, t. CXXI, nr 3, s. 541-569.

Kardasz C., Rynek kredytu pieniężnego w miastach potudniowego pobrzeża w późnym średniowieczu (Greifswald, Gdańsk, Elblag, Toruń, Rewel), Toruń 2013.

Karpińska M., Badania dziejów kobiet w Polsce w epoce nowożytnej (wiek XVI-XVIII), [w:] Dzieje kobiet w Polsce. Dyskusja wokót przysztej syntezy, red. K.A. Makowski, Poznań 2014, s. 53-74.

Karpiński A., Kobieta w mieście polskim w drugiej potowie XVI i w XVII wieku, Warszawa 1995.

Karpiński A., Przekupki wileńskie w drugiej potowie XVII i w początkach XVIII wieku, [w:] Per mulierem... Kobieta $w$ dawnej Polsce - wśredniowieczu i dobie staropolskiej, red. K. Justyniarska-Chojniak, S. Konarska-Zimnicka, Warszawa 2012, s. 369-393.

Karpiński A., Więźniowie poznańskiego ratusza w latach 1790-1793, „Przegląd Historyczny” 2014, t. CV, z. 3, s. 379-398.

Karpiński A. (rec.), M. Kamler, Przemoc między szlachtą sieradzka w XVII wieku. Opis zjawiska, Warszawa 2011, „Kwartalnik Historyczny” 2012, t. CXIX, nr 3, s. 614-620.

Karpiński A. (rec.), R. Poniat, Stużba domowa w miastach na ziemiach polskich od potowy XVIII do końca XIX wieku, Warszawa 2014, „Przegląd Historyczny” 2015, t. CVI, z. 2, s. 395-402.

Kicińska U., Oracja pogrzebowa jako upamiętnienie zmartego, [w:] Nie wszystek umrę. Pamięć o zmartych w kulturze staropolskiej, red. A. Jankowska, A. Klonder, Bydgoszcz 2015, s. 189-199.

Kicińska U., Problem ptodności i bezptodności w oracjach pogrzebowych XVII wieku poświęconych kobietom, [w:] W kregu rodziny epok dawnych. Dziecinstwo, red. B. Popiołek, A. Chłosta-Sikorska, M. Gadocha, Warszawa 2014, s. 125-140.

Kicińska U., Relacje patron-stuga w świetle korespondencji ekonomicznej Elżbiety z Lubomirskich Sieniawskiej, kasztelanowej krakowskiej, [w:] Tożsamość kobiet w Polsce: interpretacje, t. I (Od czasów najdawniejszych do XIX wieku), red. I. Maciejewska, Olsztyn 2016, s. 61-74. 
Kicińska U., Wzorzec szlachcianki w polskich drukowanych oracjach pogrzebowych XVII wieku, Warszawa 2013.

Kitowski P., „Idąc za wola Najwyższego Boga”. Kontrakt ślubny w praktyce prawa ziemskiego Prus Królewskich (1598-1772), [w:] Dom. Codzienność i święto. Ceremonie i tradycje rodzinne. Studia historyczno-antropologiczne, red. B. Popiołek, A. Chłosta-Sikorska, M. Gadocha, Kraków 2018, s. 83-92.

Klonder A. (rec.), U. Świderska-Włodarczyk, Homo Nobilis. Wzorzec szlachcica w Rzeczypospolitej w XVI i XVII wieku, Warszawa 2017, „Kwartalnik Historii Kultury Materialnej” 2018, t. LXVI, nr 1, s. 111-114.

Kobieta i wtadza w czasach dawnych, red. B. Czwojdrak, A.A. Kluczek, Katowice 2015.

Kobieta niepoznana na przestrzeni dziejów, red. A. Obara-Pawłowska, A. Miączewska, D. Wróbel, Lublin 2017.

Kocela W., Trudna sztuka babienia. Kultura medyczna Polski w II potowie XVIII wieku, Warszawa 2020.

Kolarska M., Listy Elżbiety z Branickich i Jana Tarto jako przyktad korespondencji mitosnej w epoce saskiej, [w:] Kobiece kregi korespondencyjne w XVII-XIX wieku, red. B. Popiołek, U. Kicińska, A. Staby, Warszawa-Bellerive-sur-Allier 2016, s. 79-90.

Kołacz-Chmiel M., Kobieta w rodzinie i spoteczności chtopskiej na pograniczu polsko-ruskim. Stan i perspektyw badań, [w:] Region i regionalizm $w$ archeologii $i$ historii, red. J. Hoff, S. Kadrow, Rzeszów 2013, s. 184-196.

Kołacz-Chmiel M., Mulier honesta et labioriosa. Kobieta w rodzinie chtopskiej późnośredniowiecznej Matopolski, Lublin 2018.

Kołacz-Chmiel M., Nieletni pochodzenia chtopskiego w praktyce sądów kościelnych w póżnośredniowiecznej Matopolsce, [w:] Dzieciństwo i starość w ujęciu historyków, red. A. Obara-Pawłowska, M. Kołacz-Chmiel, Lublin 2016, s. 207-226.

Kołodziejczyk K., Rodzina w parafii Nowy Korczyn w drugiej potowie XVIII wieku na podstawie ksiag metrykalnych (część 1), „Przeszłość Demograficzna Polski” 2016, t. XXXVIII, nr 3, s. 55-78.

Kołodziejczyk K., Rodzina w parafii Nowy Korczyn w drugiej potowie XVIII wieku na podstawie ksiag metrykalnych (część 2), „Przeszłość Demograficzna Polski” 2017, t. XXXIX, s. 65-95.

Korczak-Siedlecka J., Model wychowania dziewcząt w szesnastowiecznej Polsce, „Odrodzenie i Reformacja w Polsce" 2013, t. LVIII, s. 49-71.

Korczyńska A., Rola i pozycja kobiety w staropolskich ekonomikach, „In Gremium” 2016, t. X, s. $75-86$.

Kościelna J., Dzieciobójstwo i zabójstwo dziecka w Chojnie (Königsberg in der Neumark) od końca XVI do początków XVIII w., „Nadwarciański Rocznik Historyczno-Archiwistyczny” 2014, t. XXI, s. 87-121.

Kowalczyk M.E., Zagraniczne podróże Polek w epoce oświecenia, Łomianki 2019.

Kowalczyk M.E., „Żona moja, która mnie zawsze najlepiej kochata, [...] dusza cata okazuje się mnie nienawidzič", czyli problemy matżeńskie Agnieszki i Stanistawa Treterów, [w:] Kobieta i mężczyzna: jedna przestrzeń - dwa światy, red. B. Popiołek, A. Chłosta-Sikorska, M. Gadocha, Warszawa 2015, s. 369-377. 
Krzysztofik M., Siedemnastowieczna refleksja o rolach kobiety $i$ mężczyzny $w$ matżeństwie (na podstawie kazań pogrzebowych), „Res Gestae” 2016, t. III, s. 5-18.

Kuklo C., Czy reformacja wptynęta na struktury demograficzne rodziny i jej funkcjonowanie w epoce staropolskiej, „Czasy Nowożytne” 2018, t. XXXI, s. 55-71.

Kuklo C., Kobieta samotna w spoteczeństwie miejskim u schytku Rzeczypospolitej szlacheckiej. Studium demograficzno-spoteczne, Białystok 1998.

Kuklo C., Rodzina w osiemnastowiecznej Warszawie, Białystok 1991.

Kuklo C., Single Women in Pre-Industrial Towns as a Subject of Historical Research, [w:] Society and Culture Poland in Europe. Studies in Social and Cultural History. Poland at the 18-th International Congress of Historical Sciences in Montreal, ed. M. Bogucka, Warszawa 1995, s. $112-123$.

Kuras K., Dwór królowej Marii Leszczyńskiej. Ludzie, pieniądze, wptywy, Kraków 2018.

Kuras K., Rola wybitnych kobiet w polityce w czasach panowania Augusta III Sasa, [w:] Per mulierem... Kobieta w dawnej Polsce - w'średniowieczu i dobie staropolskiej, red. K. Justyniarska-Chojniak, S. Konarska-Zimnicka, Warszawa 2012, s. 261-277.

Kurowska H., Akuszerka na ziemiach polskich w świetle przepisów i literatury medycznej z końca XVIII i pierwszej potowy XIX wieku, „Studia Zachodnie” 2015, t. XVII, s. 219-238.

Kurowska H., Terminologia potożnicza w polskich drukowanych podręcznikach akuszerii $i$ anatomii z II potowy XVIII wieku, „Medycyna Nowożytna” 2018, t. XXIV, z. 3 (suplement), s. $153-170$.

Liedke M., Demografia rodziny magnackiej $w$ Wielkim Ksiestwie Litewskim na tle elit zachodnioeuropejskich. Wybrane problemy, „Przeszłość Demograficzna Polski” 2015, t. XXX, nr 1, s. 37-70.

Liedke M., Rodzina magnacka w Wielkim Księstwie Litewskim w XVI-XVIII wieku. Studium demograficzno-spoteczne, Białystok 2016.

Liedke M., Uwagi o wieku uprawniającym do zawarcia matżenstwa w Wielkim Księstwie Litewskim w XVI-XVIII wieku, „Przeszłość Demograficzna Polski” 2013, t. XXXII, s. 7-24.

Liedke M., Z badań nad prokreacja magnaterii Wielkiego Księstwa Litewskiego w XVI-XVIII wie$k u$, „Przeszłość Demograficzna Polski” 2010, t. XXIX, s. 7-27.

Liedke M., Zróżnicowanie wyznaniowe a postawy prokreacyjne magnaterii Rzeczypospolitej w XVI i w pierwszej potowie XVII wieku, „Przeszłość Demograficzna Polski” 2017, t. XXXIX, s. $49-63$.

Litak S., Edukacja początkowa w polskich szkotach w XIII-XVIII wieku, Lublin 2010.

Łozowski P., Demografia rodziny mieszczańskiej w Starej Warszawie w pierwszej potowie XV wieku, „Przeszłość Demograficzna Polski” 2014, t. XXXIV, s. 7-24.

Łozowski P., Kredyt i dom. Rynki obrotu pieniężnego i nieruchomości w Warszawie okresu XV i początków XVI wieku, Białystok 2020.

Łozowski P., Stan badań nad kobietami w miastach późnośredniowiecznych na ziemiach polskich, „Przeszłość Demograficzna Polski” 2015, t. XXXVII, nr 1, s. 71-91.

Łysiak-Łątkowska A., Wptyw polskich arystokratek na aranżowanie matżeństw od drugiej potowy XVIII do poczattku XIX wieku, [w:] Historie nieobojętne, t. II (Kądziel-kotyska - toże. 
Atrybuty kobiecości na przestrzeni dziejów), red. A. Głowacka-Penczyńska, K. Grysińska-Jarmuła, M. Opioła-Cegiełka, Bydgoszcz 2017, s. 151-166.

Maciejewska I., Mitość i erotyzm w piśmiennictwie czasów saskich, Olsztyn 2013.

Maludzińska M., „Próżnowanie stato siępowszechnym natogiem”. Żebracy i wtóczędzy w stanistawowskiej Warszawie, Warszawa 2014.

Manyś B., O problemach zdrowotnych magnackich dzieci w XVIII w. na przyktadzie potomstwa Michata Kazimierza Radziwitta zw. „Rybeńko” i Anny z Mycielskich Radziwittowej, „Medycyna Nowożytna” 2018, t. XXIV, z. 2, s. 85-102.

Manyś B., Uroczystości rodzinne w Wilnie za panowania Augusta III (1733-1763), Poznań 2014.

Manyś B., Więzi emocjonalne między matżonkami w testamentach mieszkańców Wilna i jego okolic z lat 1733-1763, [w:] Kobieta i mężczyzna: jedna przestrzeń - dwa światy, red. B. Popiołek, A. Chłosta-Sikorska, M. Gadocha, Warszawa 2015, s. 95-106.

Markuszewska A., Festa i muzyka na dworze Marii Kazimiery Sobieskiej w Rzymie (1699-1714), Warszawa 2012.

Markuszewska A., Kompozytorki i patronki muzyki w XVII i XVIII wieku. Wybrane portrety, Warszawa 2017.

Mazurkowa B., Nowy Grand Tour w'świetle „Mes Voyages” Walerii Tarnowskiej, [w:] Polski Grand Tour w XVIII i poczattkach XIX wieku, red. A. Roćko, Warszawa 2014, s. 153-182.

Medicina antiqua, mediaevalis et moderna. Historia - fllozofia - religia, red. S. Konarska-Zimnicka, L. Kostuch, B. Wojciechowska, Kielce 2019.

Mitość idealna, mitość dziecka, red. B. Płonka-Syroka, A. Szlagowska, A. Syroka, K. Marchel, Wrocław 2013.

Mitość sprzedajna, red. B. Płonka-Syroka, K. Marchel, A. Syroka, Wrocław 2014.

Nie wszystek umrę. Pamięć o zmartych w kulturze staropolskiej, red. A. Jankowska, A. Klonder, Bydgoszcz 2015.

Nietyksza M., Wierzbicka M., Profesor Anna Żarnowska - gtówne nurty badań, [w:] A. Żarnowska, Kobieta i rodzina w przestrzeni wielkomiejskiej na ziemiach polskich $w$ XIX i XX wieku, red. A. Janiak-Jasińska, K. Sierakowska, A. Szwarc, Warszawa 2013, s. IX-XX.

Obremski K., Glosa polemiczna do Radostawa Grześkowiaka „Rozwiązywania Gadki Jana Kochanowskiego, „Odrodzenie i Reformacja w Polsce” 2017, t. LXI, s. 303-306.

Opaliński E., Aktywność kobiet w życiu publicznym w czasach pierwszych Wazów, [w:] Per mulierem... Kobieta w dawnej Polsce - wśredniowieczu i dobie staropolskiej, red. K. Justyniarska-Chojniak, S. Konarska-Zimnicka, Warszawa 2012, s. 233-248.

Pamiętnik XV Powszechnego Zjazdu Historyków Polskich, t. II (Przemiany spoteczne a model rodziny), red. A. Żarnowska, Gdańsk-Toruń 1995.

Pelczar R., Szkoty trywialne dla dziewcząt w tacińskiej diecezji przemyskiej w czasach zaborów, „Przegląd Historyczno-Oświatowy” 2014, t. LVII, nr 1-2, s. 20-41.

Pelczar R., Zakon Benedyktynek na Rusi Czerwonej w XVI-XVIII w. Dynamika rozwoju i gtówne kierunki dziatalności, [w:] Klasztory mnisze na wschodnich terenach dawnej Rzeczypospolitej od XVI do początków XX wieku, red. J. Gwioździk, R. Witkowski, A.M. Wyrwa, Poznań 2014, s. 161-169. 
Penkała A., „Od postanowienia wspólnego ustawiczne przeklęctwa, stów nieuczciwych wotania, hatasy". (Nie)codzienność szlacheckiego domu w świetle zapisów z osiemnastowiecznych ksiag grodzkich z terenu województwa krakowskiego, [w:] Dom, codzienność i święto. Ceremonie i tradycje rodzinne. Studia historyczno-antropologiczne, red. B. Popiołek, A. Chłosta-Sikorska, M. Gadocha, Kraków 2018, s. 93-103.

Penkała A., Panieńskie ochędóstwo. Kwestie posagowe i wienne w matżeństwach szlachty województwa krakowskiego w czasach saskich, Kraków 2016.

Penkała A., Przeciw prawu, tradycji i obyczajowi. Sprawy procesowe szlacheckich matżenstw w ksiegach sądów grodzkich z terenu województwa krakowskiego w czasach saskich, Kraków 2017.

Perrot M., Mon histoire des femmes, Paris 2006 (wersja polskojęzyczna: Moja historia kobiet, przekł. M. Szafrańska-Brandt, Kraków 2009).

Pękacka-Falkowska K., Dyscyplinować i pomagać - toruńskie akuszerki miejskie w XVIII w. (kilka uwag na marginesie przysiag i porządków akuszerskich), „Medycyna Nowożytna” 2013, t. XIX, z. 2, s. 65-105.

Pękacka-Falkowska K., Drzewiecki B., Projekt porządku akuszerskiego Towarzystwa Przyrodniczego w Gdańsku (Naturforschende Gesellschaft) z 1781 r., „Medycyna Nowożytna” 2019, t. XXV, z. 2, s. 47-66.

Pielas J., Majątkowe zabezpieczenie sióstr w szlacheckich dziatach spadkowych w Koronie w XVII wieku, [w:] Per mulierem... Kobieta $w$ dawnej Polsce - w średniowieczu i dobie staropolskiej, red. K. Justyniarska-Chojniak, S. Konarska-Zimnicka, Warszawa 2012, s. 343-356.

Pielas J., Opieka nad nieletnimi w Koronie w XVIII wieku, [w:] Dzieciństwo i starość w ujęciu historyków, red. A. Obara-Pawłowska, M. Kołacz-Chmiel, Lublin 2016, s. 83-95.

Pielas J., Państwo, religia, prawo i rodzina, [w:] Rodzina i jej gospodarstwo na ziemiach polskich w geografii europejskich struktur rodzinnych do potowy XX wieku, red. P. Guzowski, C. Kuklo, Białystok 2019, s. 19-37.

Pielas J., Podziaty majątkowe szlachty koronnej w XVII wieku, Kielce 2013.

Pietrzak J., „Cate brzemię promocyi”. O kobietach z rodzin królewskich i magnackich jako o promotorkach awansów urzędniczych w Rzeczypospolitej drugiej potowy XVII wieku, [w:] Na przekór konwencjom. Nieszablonowe role spoteczne kobiet i mężczyzn od czasów nowożytnych do 1945 roku, red. M. Gibiec, D. Wiśniewska, L. Ziątkowski, Kraków 2018.

Pietrzak J., Korespondencja Katarzyny z Sobieskich ks. Radziwittowej (1634-1694) jako źródto do poznania jej relacji rodzinnych, [w:] Kobiece kregi korespondencyjne w XVII-XIX wieku, red. B. Popiołek, U. Kicińska, A. Słaby, Warszawa-Bellerive-sur-Allier 2016, s. 13-30.

Pietrzak J., Księzna dobrodziejka. Katarzyna z Sobieskich Radziwittowa (1634-1694), Warszawa 2016.

Pietrzak J., Siedemnastowieczna podróżniczka. Wrażenia Katarzyny z Sobieskich Radziwittowej z podróży po Europie Zachodniej w latach 1677-1678, [w:] Kulturowe wzorce a spoteczna praktyka. Studia z dziejów kobiet, red. A. Jakuboszczak, P. Matusik, Poznań 2012, s. $103-126$.

Pietrzak J., W szponach natogu. Alkoholizm kobiet w epoce staropolskiej na przyktadzie Joanny z Denhoffów Denhoffowej (zm. 1720), [w:] Antropologia używek w gospodarce i życiu spotecznym, red. J. Żychlińska, A. Głowacka-Penczyńska, J. Woźny, Bydgoszcz 2016, s. 57-75. 
Pietrzak J., „Zbrodnia to niestychana, Pani zabita Pana”. Sprawa Marianny z ks. Sapiehów Dąmbskiej o matżonkobójstwo - studium przypadku, [w:] Conjux, mater, filia, soror propinqua, civis... Kobieta na ziemi wschowskiej i pograniczu wielkopolsko-śląskim, red. M. Małkus, K. Szymańska, Wschowa-Leszno 2016, s. 249-281.

Pluta E., Środowisko rodzinne krakowskich norbertanek ze Zwierzyńca - przyczynek do badań nad sktadem osobowym konwentów żeńskich (XVII-XVIII w.), „Klio” 2016, t. XXXIX, nr 4, s. 77-96.

Pluta E. (rec.), J. Gwioździk, Kultura pisma i książki w żeńskich klasztorach dawnej Rzeczypospolitej XVI-XVIII wieku, Katowice 2015, „Res Gestae” 2016, t. III, s. 328-331.

Pluta E. (rec.), P. Gąsiorowska, Konwent Klarysek krakowskich do końca XVIII wieku. Studium prozopograficzne, Kraków 2015, „Studia Historyczne” 2016, t. LIX, z. 1, s. 110-113.

Polski Grand Tour w XVIII i początkach XIX wieku, red. A. Roćko, Warszawa 2014.

Poniat R., Stużba domowa w miastach na ziemiach polskich od potowy XVIII do końca XIX wieku, Warszawa 2014.

Poniat R. (rec.), M. Maludzińska, „Próżnowanie stato się powszechnym natogiem”. Żebracy i wtóczędzy w stanistawowskiej Warszawie, Warszawa 2014, „Przegląd Historyczny” 2016, t. CVII, z. 2, s. 311-327.

Popiołek B., Dobrodziejki i klienci. Specyfika patronatu kobiecego i relacji klientalnych w czasach saskich, Warszawa 2020.

Popiołek B., Męska zbrodnia, kobiecy ból. Drobna przemoc w czasach saskich, [w:] Kobieta i mężczyzna: jedna przestrzeń - dwa światy, red. B. Popiołek, A. Chłosta-Sikorska, M. Gadocha, Warszawa 2015, s. 83-93.

Popiołek B., Między przestrzenia domowa a wielka polityka. Aktywność publiczna kobiet w czasach saskich, [w:] Drogi kobiet do polityki (na przestrzeni XVIII-XXI wieku), red. T. Kulak, M. Dajnowicz, Wrocław 2016, s. 27-44.

Popiołek B., „W wielkim strachu i bojaźni rezydujem...”. Mentalność zakonnic w okresie saskim. Próba sondażu, [w:] Klasztory mnisze na wschodnich terenach dawnej Rzeczypospolitej od XVI do początków XX wieku, red. J. Gwioździk, R. Witkowski, A.M. Wyrwa, Poznań 2014, s. 183-193.

Przetomy w historii. XVI Powszechny Zjazd Historyków Polskich, Wroctaw 15-19 września 1999 r. Pamiętnik, red. K. Ruchniewicz, J. Tyszkiewicz, W. Wrzesiński, t. III, cz. 4, Toruń 2001.

Przybyłowicz O.M., Jak panny zakonne rozliczaty się? Księgi rachunkowe jako źródto do badań nad polskimi klasztorami żenskimi w XVI-XVIII w., [w:] Klasztor w gospodarce średniowiecznej i nowożytnej, red. M. Derwich, Wrocław 2013, s. 105-108.

Przybyłowicz O.M., Klasztor klarysek w Strzelnie - uposażenie, darowizny, dochody. Przyczynek do standardu życia wspólnoty w świetle prawa zakonnego i dokumentów, „Śląski Kwartalnik Historyczny Sobótka” 2016, t. LXXI, nr 2, s. 19-46.

Przybyłowicz O.M., Reguta zakonna jest wozem do nieba. Realia życia w klasztorach klarysek od XIII do końca XVI w Matopolsce, Wielkopolsce i na Ślasku, Warszawa 2016. 
Przybyłowicz O.M., Źródta do poznania gospodarki w dobrach wiejskich klarysek gnieźnieńskich od końca XVI do schytku XVII stulecia, „Kwartalnik Historii Kultury Materialnej” 2017, t. LXV, nr 4, s. 447-459.

Roćko A., Grand Tour „Dam Modnych”, [w:] Polski Grand Tour w XVIII i poczatkach XIX wieku, red. A. Roćko, Warszawa 2014, s. 131-150.

Rodak M. (rec.), M. Maludzińska, „Próżnowanie stato się powszechnym natogiem”. Żebracy i wtóczędzy w stanistawowskiej Warszawie, Warszawa 2014, „Roczniki Dziejów Społecznych i Gospodarczych” 2016, t. LXXVI, s. 505-508

Rok B., Europa drugiej potowy XVIII wieku w oczach polskiej podróżniczki Teofili Konstancji $z$ Radziwittów Morawskiej, [w:] Europejski wiek oświecenia: uniwersalizm myśli, różnorodność dróg, red. M. Dębowski, A. Grześkowiak-Krwawicz, M. Zwierzykowski, Kraków 2013, s. 221-233.

Rok B., Wyobrażenie mężczyzny i kobiety w staropolskich poradnikach artis bene vivendi, [w:] Kobieta i mężczyzna: jedna przestrzeń - dwa światy, red. B. Popiołek, A. Chłosta-Sikorska, M. Gadocha, Warszawa 2015, s. 483-492.

Rok B., Wyprawa Teofili Konstancji z Radziwittów Morawskiej do Neapolu w 1774 r., [w:] Klio viae et India. Opuscula Marco Cetwiński dedicata, red. A. Odrzywolska-Kidawa, Warszawa 2010, s. 521-527.

Siebel J., Ludność parafii Bogucickiej (województwo śląskie) w latach 1738-1860 (na podstawie ksiag metrykalnych), Katowice 2012.

Skierska J., Ludność Zielonej Góry w latach 1652-1766 w świetle ksiag metrykalnych, Zielona Góra 2015.

Słaby A., Rządzicha oleszycka. Dwór Elżbiety z Lubomirskich Sieniawskiej jako przyktad patronatu kobiecego w czasach saskich, Kraków 2014.

Słaby A. (rec.), P. Tyszka, W cieniu wielkiego kanclerza. Barbara z Tarnowskich Zamoyska, Warszawa 2015, „Czasy Nowożytne” 2017, t. XXX, s. 205-214.

Stynne kobiety w Rzeczypospolitej XVIII wieku, red. A. Roćko, M. Górska, Warszawa 2017.

Srogosz T. (rec.), M. Maludzińska, „Próżnowanie stato się powszechnym natogiem”. Żebracy i wtóczędzy w stanistawowskiej Warszawie, Warszawa 2014, „Kwartalnik Historyczny” 2016, t. CXXII, nr 2, s. 378-382.

Stawiak-Ososińska M., Sztuka potożnicza dla kobiet. Ksztatcenie akuszerek na ziemiach polskich $w$ dobie niewoli narodowej (1773-1914), Warszawa 2019.

Stefaniak P., Dzieje tercjarek dominikańskich „de Poenitentia” we Lwowie (1293-1740), „Nasza Przeszłość" 2014, t. CXXI, s. 75-102.

Stojek-Sawicka K., Szlachcianki w świecie sarmackim. Jak żyty kobiety na dworach szlacheckich $w$ dawnej Polsce, Warszawa 2013.

Stuchlik-Surowiak B., Obraz matżenstwa w ,antyfeministycznych” utworach Bartosza Paprockiego na tle obyczajowych, religijnych oraz literackich zjawisk XVI i pierwszej potowy XVII wieku, Katowice 2016. 
Surdacki M., Rodzina i jej problemy w Urzędowie w czasach staropolskich, [w:] Spoteczeństwo staropolskie. Seria nowa, t. III (Spoteczeństwo a rodzina), red. A. Karpiński, Warszawa 2011, s. 227-244.

Szapczyński P., Anna I Jagiellonka kontra Jan Zamoyski. Kilka uwag w sprawie dążén królowej do zapewnienia ciagtości dynastii Jagiellonów, „Klio” 2014, t. XXVIII, nr 1, s. 3-29.

Sztylc K.Ż., The Abbas Magdalena Morteska (1554-1631). Her life and reformist initiatives aimed at female education in the post-tridentine era, „Roczniki Teologiczne” 2016, t. LXIII, z. 4, s. 53-73.

Szwarc A., Flirt jako przedmiot badań historycznych, „Przegląd Historyczny” 2014, t. CV, z. 1, s. 121-128.

Szylar A., Bractwa religijne przy klasztorach żeńskich XVIII wieku, [w:] Bractwa religijne w średniowieczu i w okresie nowożytnym (do końca XVIII wieku), red. D. Burdzy, B. Wojciechowska, Kielce 2014, s. 167-182.

Szylar A., Dziatalność wychowawczo-edukacyjna żeńskich zgromadzeń zakonnych w Matopolsce wokresie potrydenckim do 1815 roku, Kraków 2012.

Szylar A., Ideaty wychowawcze w klasztornych szkotach żeńskich w okresie potrydenckim do poczatków XIX wieku, „Paedagogia Christiana” 2012, nr XXX(II), s. 11-27.

Szylar A., „Naprzód zaraz wstana, kiedy ich obudza...”, czyli panny świeckie na edukacji u wizytek warszawskich, [w:] Per mulierem... Kobieta $w$ dawnej Polsce - w średniowieczu i dobie staropolskiej, red. K. Justyniarska-Chojniak, S. Konarska-Zimnicka, Warszawa 2012, s. 211-230.

Szylar A., "Potrzeby do pożytku należące” - rozrzutność czy skąpstwo? O wydatkach mniszek w XVIII wieku w księgach ekspensy, [w:] Kobieta i mężczyzna: jedna przestrzeń - dwa światy, red. B. Popiołek, A. Chłosta-Sikorska, M. Gadocha, Warszawa 2015, s. 345-356.

Szylar A., „Sprawa o tym, jak benedyktynki gospodarstwo prowadzity.... Organizacja i funkcjonowanie gospodarki opactwa benedyktynek w Sandomierzu w XVII i XVIII w., [w:] Klasztor w gospodarce średniowiecznej i nowożytnej, red. M. Derwich, Wrocław 2013, s. 447-459.

Szylar A., "Zostawili córki trzy na edukacje u nas...”, czyli o klasztornym wychowaniu dziewcząt w XVIII i na poczatku XIX wieku, [w:] W kregu rodziny epok dawnych. Dziecinstwo, red. B. Popiołek, A. Chłosta-Sikorska, M. Gadocha, Warszawa 2014, s. 323-338.

Świderska U., Szlachecki wzorzec osobowy gospodyni w Polsce przetomu średniowiecza i czasów renesansu, [w:] Kobieta w gospodarstwie domowym. Ziemie polskie na tle porównawczym, red. K. Sierakowska, G. Wyder, Zielona Góra 2012, s. 21-27.

Świderska-Włodarczyk U., Homo Nobilis. Wzorzec szlachcica w Rzeczypospolitej w XVI i XVII wieku, Warszawa 2017.

Święch H., Przetożone klasztoru bernardynek pw.św. Agnieszki w Krakowie w XV-XVIII wieku, „Nasza Przeszłość” 2015, t. CXXIII, s. 113-132.

Thébaud F., Tworzenie historii kobiet we Francji. Rys historiograficzny, spory metodologiczne, relacje z instytucjami naukowymi i politycznymi, „Kwartalnik Historyczny” 2001, t. CVIII, nr 3, s. 81-98.

The Routledge History of Women in Early Modern Europe, ed. A.L. Capern, London 2006. 
Tomaszewski M. (rec.), „Gdybym Cię, moje Serce, za męża nie miata, żyć bym nie mogta”. Listy Magdaleny $z$ Czapskich do Hieronima Floriana Radziwitta z lat 1744-1759, wstęp i oprac. I. Maciejewska, K. Zawilska, Olsztyn 2016, „Czasy Nowożytne” 2018, t. XXXI, s. 359-363.

Truściński Ł., Kobieta w obliczu sądu w późnośredniowiecznym Krakowie - sprawy karne, [w:] Per mulierem... Kobieta $w$ dawnej Polsce - w'średniowieczu i dobie staropolskiej, red. K. Justyniarska-Chojniak, S. Konarska-Zimnicka, Warszawa 2012, s. 287-297.

Trzpiot W., Stan btogostawiony czy „nieznośne męki”? Kobieta staropolska w okresie ciązy i potogu w'świetle memuarów, [w:] Per mulierem... Kobieta w dawnej Polsce - w średniowieczu i dobie staropolskiej, red. K. Justyniarska-Chojniak, S. Konarska-Zimnicka, Warszawa 2012, s. 433-449.

Tyszka P., W cieniu wielkiego kanclerza. Barbara z Tarnowskich Zamoyska, Warszawa 2015.

Urbanek B. (rec.), M. Stawiak-Ososińska, Sztuka potożnicza dla kobiet. Ksztatcenie akuszerek na ziemiach polskich $w$ dobie niewoli narodowej (1773-1914), Warszawa 2019, „Medycyna Nowożytna” 2019, t. XXV, z. 1, s. 181-186.

W kregu rodziny epok dawnych. Dzieciństwo, red. B. Popiołek, A. Chłosta-Sikorska, M. Gadocha, Warszawa 2014.

Węglorz J., Staropolskie poradniki medyczne o zdrowiu i chorobach kobiet, [w:] Per mulierem... Kobieta $w$ dawnej Polsce - wśredniowieczu i dobie staropolskiej, red. K. Justyniarska-Chojniak, S. Konarska-Zimnicka, Warszawa 2012, s. 421-432.

Węglorz J., Zdrowie, choroba i lecznictwo w spoteczeństwie Rzeczypospolitej XVI-XVIII wieku, Toruń 2015.

Wiesner M.E., Women and Gender in Early Modern Europe, Cambridge 1993.

Wijaczka J., Dzieci w procesach o czary. Casus Prus Książcych w XVII wieku, „Zapiski Historyczne” 2014, t. LXXIX, z. 1, s. 101-116.

Wijaczka J., Kościót wobec czarostwa w Rzeczypospolitej w XVI-XVIII wieku (na tle europejskim), Warszawa 2016.

Wijaczka J., Procesy o czary w Gdańsku w XVI-XVII wieku, „Przegląd Historyczny” 2019, t. CX, z. 3, s 399-417.

Wijaczka J., Procesy o czary w Prusach Ksiażęcych (Brandenburskich) w XVI-XVIII wieku, wyd. 2 zmienione, Olsztyn 2019.

Wijaczka J., Próba zimnej wody (ptawienie) w oskarżeniach i procesach o czary w państwie polsko-litewskim wXVI-XVIII wieku, „Odrodzenie i Reformacja w Polsce” 2016, t. LX, s. 73-110.

Wijaczka J. (rec.), Codzienne ktopoty, wielkie interesy i podwójna elekcja. Korespondencja radziwittowskich urzędników z księżna Anną z Sanguszków Radziwittowa i jej synem Michatem Kazimierzem 1733/1734, wyd. J. Dygdała, Warszawa 2013, „Czasy Nowożytne” 2013, t. XXVI, s. 245-247.

Wilczek-Karczewska W., Konflikty rodzinne na tle majątkowym w'sietle wielkopolskich inwentarzy i testamentów z XVII wieku. Zarys problematyki, [w:] Spoteczeństwo staropolskie. Seria nowa, t. III (Spoteczeństwo a rodzina), red. A. Karpiński, Warszawa 2011, s. 149-169.

Wiślicz T., Upodobanie. Matżeństwo i związki nieformalne na wsi polskiej XVII-XVIII wieku. Wyobrażenia spoteczne i jednostkowe doświadczenia, Wrocław 2012. 
Wiślicz T., Wiejskie zaloty w Polsce XVII-XVIII wieku. Sposoby doboru partnera seksualnego i kryteria atrakcyjności $w$ środowisku chtopskim Rzeczypospolitej w okresie „przedetnograficznym”, „Studia Historica Gedanensia” 2012, t. III (Historia flirtu), red. P. Perkowski, s. 37-57.

Wojciechowska B., Matżeństwo w ustawodawstwie synodalnym Kościota polskiego w późnym średniowieczu, „Czasopismo Prawno-Historyczne” 2015, t. LXVII, nr 1, s. 21-29.

Wojciechowska B., Porady dla kobiet cięzarnych i rodzących w wybranych pracach od późnego antyku do wczesnej nowożytności, „Medycyna Nowożytna” 2014, t. XX, z. 1, s. 145-151.

Wojciechowska B., Proles - fides - sacramentum. Matżeństwo w średniowiecznym prawie kanonicznym, [w:] Kobieta i mężczyzna: jedna przestrzeń - dwa światy, red. B. Popiołek, A. Chłosta-Sikorska, M. Gadocha, Warszawa 2015, s. 17-26.

Wolański F., Rozważne Panny i Dzielni Kawalerowie. Kulturowy status ptci w bernardyńskim dyskursie kaznodziejskim epoki saskiej, [w:] Kobieta i mężczyzna: jedna przestrzeń - dwa światy, red. B. Popiołek, A. Chłosta-Sikorska, M. Gadocha, Warszawa 2015, s. 493-501.

Wróbel Ł., Dziatalność fundacyjna i oświatowa szlachty inflanckiej w XVIII wieku na przyktadzie rodzin Borchów, Platerów i Hylzenów, [w:] Studia z dziejów edukacji w Rzeczypospolitej Obojga Narodów Korony i Litwy, red. K. Puchowski, J. Orzeł, Warszawa 2019, s. 123-139.

Wunder H., „Er ist die Sonn', sie ist der Mond”. Frauen in der Frühen Neuzeit, München 1992.

Wyczański A., Kobiety - kierowniczki folwarków w starostwie sieradzkim w XVI w., „Zapiski Historyczne" 1976, t. XLI, z. 3, s. 41-49.

Wyczański A., Wyrobisz A., La famille et la vie économique, „Studia Historiae Oeconomicae” 1983 (1985), t. XVIII, s. 56-68.

Wyrobisz A., Rodzina w mieście doby przedprzemystowej a życie gospodarcze. Przegląd badań i problemów, „Przegląd Historyczny” 1986, t. LXXVII, z. 2, s. 305-330.

Wyrobisz A., Staropolskie wzorce rodziny i kobiety - żony i matki, „Przegląd Historyczny” 1992, t. LXXXIII, z. 3, s. 405-421.

Wyżga M., Zty los Matgosi Madejszczonki? Mikrohistoria spod osiemnastowiecznego Ojcowa, [w:] Kobieta i mężczyzna: jedna przestrzeń - dwa światy, red. B. Popiołek, A. Chłosta-Sikorska, M. Gadocha, Warszawa 2015, s. 307-315.

Ziontek A., Siedlecki dwór artystyczny Aleksandry Ogińskiej, [w:] Mate miasta. Spoteczność, red. M. Zemło, Lublin 2011, s. 247-270.

Żarnowska A., Studia nad dziejami kobiet w dzisiejszej historiografii polskiej, „Kwartalnik Historyczny” 2001, t. CVIII, nr 3, s. 99-116.

Żołądź-Strzelczyk D., „A cacek tė̇ dużo byto”. Zabawki dziecięce na ziemiach polskich $w$ średniowieczu i epoce nowożytnej, „Kwartalnik Historyczny” 2013, t. CXX, nr 1, s. 5-30.

Żołądź-Strzelczyk D., Antoniego Maksymiliana Prokopowicza „Sposób nowy najtatwiejszy pisania i czytania razem dla panienek z przypisami dla nauczycielek" - pierwszy polski podręcznik edukacji elementarnej dla dziewcząt, „Kwartalnik Historii Kultury Materialnej” 2014, t. LXII, nr 4, s. 553-565.

Żołądź-Strzelczyk D., Dzieciństwo w epoce staropolskiej - możliwości źródtowe i kierunki badań, [w:] Dzieciństwo i starość w ujęciu historyków, red. A. Obara-Pawłowska, M. Kołacz-Chmiel, Lublin 2016, s. 227-242. 
Żołądź-Strzelczyk D., Osobisty i spoteczny wymiar bezdzietności w dawnej Polsce, [w:] Gospodarka, spoteczeństwo, kultura w dziejach nowożytnych. Studia ofiarowane Pani Profesor Marii Boguckiej, red. A. Karpiński, E. Opaliński, T. Wiślicz, Warszawa 2010, s. 103-112.

Żołądź-Strzelczyk D., „Pod każdym względem szlachetne ci daje wychowanie...”. Studia z dziejów wychowania szlachty w epoce staropolskiej, Wrocław 2017.

Żołądź-Strzelczyk D., Rola zabawek w przygotowaniu do petnienia funkcji spotecznych kobiecych i meskich w epoce nowożytnej, [w:] Kobieta i mężczyzna: jedna przestrzeń - dwa światy, red. B. Popiołek, A. Chłosta-Sikorska, M. Gadocha, Warszawa 2015, s. 469-482.

Żołądź-Strzelczyk D., Kabacińska-Łuczak K., Codzienność dziecięca opisana stowem i obrazem. Życie dziecka na ziemiach polskich od XVI do XVIII wieku, Warszawa 2012.

Żurek D., Matżeństwa mieszczan Chrzanowa do potowy XVII wieku, [w:] Kobieta i mężczyzna: jedna przestrzeń - dwa światy, red. B. Popiołek, A. Chłosta-Sikorska, M. Gadocha, Warszawa 2015 , s. $47-55$.

\section{Notka o autorze:}

prof. dr hab. Cezary Kuklo - kierownik Katedry Historii Struktur Demograficznych, Gospodarczych i Religijnych oraz dyrektor Centrum Badań Struktur Demograficznych i Gospodarczych Przednowoczesnej Europy Środkowo-Wschodniej na Wydziale Historii i Stosunków Międzynarodowych Uniwersytetu w Białymstoku. Wiceprzewodniczący Komitetu Nauk Historycznych PAN i wiceprezes Polskiego Towarzystwa Historycznego.

Zainteresowania badawcze: historia społeczna i gospodarcza Polski i powszechna doby nowożytnej, demografia historyczna, historia rodziny i kobiet, procesy modernizacyjne społeczeństwa w XIX w.

అ.kuklo@uwb.edu.pl 